\title{
TREE-RING WIDTHS AND THE STABLE ISOTOPE COMPOSITION OF PINE TREE-RINGS AS CLIMATE INDICATORS IN THE MOST INDUSTRIALISED PART OF POLAND DURING $\mathrm{CO}_{2}$ ELEVATION
}

\author{
BARBARA SENSULA ${ }^{1}$ and SŁAWOMIR WILCZYŃSKI ${ }^{2}$ \\ ${ }^{1}$ Silesian University of Technology, Institute of Physics - Center for Science and Education, Konarskiego 22B, Gliwice 44-100, Poland \\ ${ }^{2}$ Department of Forest Protection, Entomology and Forest Climatology, University of Agriculture in Krakow, \\ Al. 20 Listopada 46, Kraków 31-425, Poland
}

Received 12 October 2017

Accepted 6 June 2018

\begin{abstract}
Scots pine (Pinus sylvestris L.) growing in 16 sites in three industrial regions in Poland was analysed to delineate dendroclimatologically uniform areas. A dendrochronological and mass spectrometric analysis revealed the following: a dry and sunny previous September, low winter temperature, and moisture supply in July limit the radial growth of the pines in all the regions. The weather conditions of the current growing season have been the most strongly reflected in the isotopic ratio. Positive relationships were noted between $\delta^{13} \mathrm{C}$ and temperature and $\delta^{13} \mathrm{C}$ and sunshine. A negative relationship was observed between $\delta^{13} \mathrm{C}$ and precipitation and $\delta^{13} \mathrm{C}$ and humidity. At the same time, a positive relationship was noted between $\delta^{18} \mathrm{O}$ and sunshine and $\delta^{18} \mathrm{O}$ and temperature, but negative between $\delta^{18} \mathrm{O}$ and humidity. The climate signal recorded in the stable isotope composition was temporally unstable and only for a few of the climatic parameters did we find temporally stable climate signals. However, variability in the strength and direction of the relationships between variables has been observed. In general, the weather in July and August is important for determining the $\delta^{13} \mathrm{C}$ and $\delta^{18} \mathrm{O}$ signals. Instability can reflect the physiological adaptation of the plants to changes in the ecosystem.
\end{abstract}

Keywords: climate, stable carbon isotopes, stable oxygen isotopes, pine tree-rings, industrial region, Silesia.

\section{INTRODUCTION}

Scots pine is a very useful archive of changes in ecosystems, because it has a specific sensitivity to local environmental conditions, including climate. (Schweingruber, 1985; Richter et al., 1991; Lindholm et al., 1997, 2000; Mäkinen et al., 2000; Wilczyński et al., 2001; Wilczyński and Skrzyszewski, 2002; Macias et al., 2004). Various indicators, such as an increase in the stem diameter, can

Corresponding author: B. Sensuła e-mail: Barbara.Sensula@polsl.pl be used to describe tree vitality. Furthermore, the diameter increment can also be used to assess the sensitivity of trees to climatic factors in polluted areas (Malik et al., 2012).

Year-on-year variations in tree-ring widths are mainly caused by meteorological conditions. Industrial pollution impairs the sensitivity of trees to climatic factors. However, the trees retain their year-on-year tree-ring width changes, even during periods of high-pollution emissions.

Experiments and analyses of the stable isotope composition of annual tree rings conducted by various scientists (e.g., Craig, 1954; Burk and Stuiver, 1981; Leavitt and Long, 1982; Edwards and Fritz, 1986; Ehrelinger and Vogel, 1993; Farquhar and Lloyd, 1993; Yoder et al., 
1994; Schleser et al., 1999; Roden et al., 2000, Roden, 2008; Barbour et al., 2002, 2004; Gagen et al., 2004; McCarroll and Loader, 2004; Szczepanek et al., 2006; Treydte et al., 2007; Sensuła et al., 2011; Leonelli et al., 2012; Sensuła, 2016a), have confirmed that the stable isotope composition of wood can be varied by climatic changes. Through photosynthesis, trees convert carbon dioxide and water into saccharides $\left(\mathrm{C}_{6} \mathrm{H}_{12} \mathrm{O}_{6}\right)_{\mathrm{n}}$ by using light. The climatic controls are therefore factors which control stomatal conductance, and are dominated by relative air humidity and soil-moisture status, while those which control the photosynthetic rate are dominated by light levels and leaf temperature (McCaroll and Loader, 2004). The $\delta^{18} \mathrm{O}$ of cellulose might also depend on the isotopic composition of water used during photosynthesis (Burk and Stuiver, 1981; Edwards and Fritz, 1986; Yakir et al., 1990; Saurer et al., 1997a; Anderson et al., 1998; Switsur and Waterhouse, 1998; Barbour et al., 2002; 2004; Saurer et al., 2002, 1997b). Farquhar and Lloyd (1993) and Roden et al. (2000) have reported that the oxygen isotopic composition of trees $\left(\delta^{18} \mathrm{O}\right)$ can be influenced by the $\delta^{18} \mathrm{O}$ in meteoric water and the $\delta^{18} \mathrm{O}$ of atmospheric vapour. Patterns in the $\delta^{18} \mathrm{O}$ of meteoric precipitation reflect condensation and evaporation within air masses (Siegenthaler and Oeschger, 1980; Rozanski et al., 1993). Schleser et al. (1999) has found that changes in temperature coefficients can be due to the nonlinear transformation of environmental signals through biological systems.

A combination of several independent indicators constitutes a useful tool in environmental analysis, such as in dendrochronological and climatological research. Scientists attribute the variations in the stable isotope composition to climate changes, and also to anthropogenic effects (Gagen et al., 2011; Leonelli et al., 2012; Sensuła and Pazdur, 2013a, 2013b; Sensuła, 2016b). A decrease in the $\delta^{13} \mathrm{C}$ concentration in the air and the biosphere is associated with an increase in the $\mathrm{CO}_{2}$ concentration in the atmosphere (Craig, 1954; Farquhar and Lloyd, 1993; Saurer et al., 2002; McCarroll and Loader, 2004, McCarroll et al., 2009; Pazdur et al., 2007, 2013; Keeling et al., 1996; Rinne et al., 2010; Sensuła and Pazdur, 2013a, 2013b; Battipaglia et al., 2013). The average global atmospheric $\mathrm{CO}_{2}$ concentration has risen from $331 \mathrm{ppm}$ in 1975 to 393 ppm in 2012 (NOAA). Raw $\delta^{13} \mathrm{C}$ data can be corrected to a pre-industrial atmospheric $\delta^{13} \mathrm{C}$ (McCarroll and Loader, 2004; McCarroll et al., 2009, NOAA).

According to Saurer and Siegwolf (2007), the stronger response of photosynthetic capacity (A) indicates that some species could enhance biomass accumulation due to the increasing $\mathrm{CO}_{2}$ during the last decade, whereas other species responded more strongly with reduced stomatal conductance and less transpiration and water loss. According to scientists (Farquhar and Lloyd, 1993; Ehlelinger and Vogel, 1993; Scheidegger et al., 2000; Saurer et al., 2004; Silva and Horwath, 2013), a com- bined analysis of carbon and oxygen isotopes in tree rings can be used for determining whether stomatal conductance $(g)$ or photosynthesis $(A)$ contribute the most to the variations in the amount of carbon acquired per unit of water lost - the $i W U E$ - intrinsic water-use efficiency) in response to environmental changes (Eq. 1.1).

$i W U E=A / g$

The observed anthropogenic impact on the carbon cycle is mainly related to various global industrial activities (Martin et al., 1988; Ferrio et al., 2003; Keeling et al., 1996; Pazdur et al., 2013; Boden et al., 2016). However, the other pollution effects go beyond the scope of this paper, and have been the subject of other publications (Sensuła, 2016a, 2016b; Sensuła et al., 2015a, 2015b; Sensuła and Wilczyński, 2017; Sensuła et al., 2017). In the literature, there is an absence of reports on climate signals recorded in respect of the tree-ring width and the stable isotope composition of trees growing in the wide Silesia region (Sensuła et al., 2015a). The aim of this study is to extend the current knowledge of the interaction between climate and the trees' response in three forests in the Silesia region (Poland), to answer the question of whether there is a similar or different pattern in the regional climate signals recorded in the trees. Further, we aim to obtain additional information on the climateradial growth relationships of pine and to examine the differences in the stable carbon and oxygen isotopic composition of $\alpha$-cellulose extracted from the pine (Pinus silvestris L.) growing, under $\mathrm{CO}_{2}$ anthropogenic-emission stress, in the most industrialised part of Poland.

\section{MATERIALS AND METHODS}

The climate-radial growth relationships were analysed for the period 1951-2012, whereas the climate-stable isotopic relationships were analysed for the period 1975 2012. The software programs Statistica 12 (Statsoft Inc. 2014, Kraków, Polska) and DendroClim2002 (Biondi, 1997) were used for the statistical analyses.

\section{Sampling sites}

The dendroclimatological sampling reported in this paper included 16 pine sites in three regions - Dąbrowa Górnicza near Huta Katowice (HK), Kędzierzyn-Koźle (KK), and Łaziska (LA). The sampling sites were located at varying distances from industrial factories (distance range: $1-20 \mathrm{~km}$ from the factories, Table 1).

At each site, 20 pine trees were sampled by taking one increment core per tree at a height of $1.3 \mathrm{~m}$ above ground. All 320 tree samples were dominant and co-dominant individuals without damage. The examined pine stands were located in similar habitat conditions around the industrial factories. All the pine stands were classified as fresh mixed broadleaved forest and aged between 80 and 100 years. 
Table 1. The localisation of the sampling sites.

\begin{tabular}{|c|c|c|}
\hline Stand (region) & Lab code & Geographical coordinates \\
\hline \multirow{6}{*}{$\begin{array}{l}\text { Kędzierzyn-Koźle } \\
\text { (KK) }\end{array}$} & KKT & $50^{\circ} 18^{\prime} \mathrm{N} ; 18^{\circ} 20^{\prime} \mathrm{E}$ \\
\hline & KKS & $50^{\circ} 18^{\prime} \mathrm{N} ; 18^{\circ} 17^{\prime} \mathrm{E}$ \\
\hline & KKB & $50^{\circ} 21^{\prime} \mathrm{N} ; 18^{\circ} 18^{\prime} \mathrm{E}$ \\
\hline & KKA & $50^{\circ} 19^{\prime} \mathrm{N} ; 18^{\circ} 15^{\prime} \mathrm{E}$ \\
\hline & KKC & $50^{\circ} 20^{\prime} \mathrm{N} ; 18^{\circ} 19^{\prime} \mathrm{E}$ \\
\hline & KKN & $50^{\circ} 22^{\prime} \mathrm{N} ; 18^{\circ} 23^{\prime} \mathrm{E}$ \\
\hline \multirow{3}{*}{$\begin{array}{l}\text { Laziska } \\
\text { (LA) }\end{array}$} & LAW & $50^{\circ} 8^{\prime} \mathrm{N} ; 18^{\circ} 53^{\prime} \mathrm{E}$ \\
\hline & LAM & $50^{\circ} 9^{\prime} \mathrm{N} ; 18^{\circ} 56^{\prime} \mathrm{E}$ \\
\hline & $\overline{\mathrm{LAP}}$ & $50^{\circ} 10^{\prime} \mathrm{N} ; 18^{\circ} 58^{\prime} \mathrm{E}$ \\
\hline \multirow{7}{*}{$\begin{array}{l}\text { Dabrowa Gornicza } \\
\text { (HK)HKB2 }\end{array}$} & HKE & $50^{\circ} 20^{\prime} \mathrm{N} ; 19^{\circ} 23^{\prime} \mathrm{E}$ \\
\hline & HKBB & $50^{\circ} 24^{\prime} \mathrm{N} ; 19^{\circ} 22^{\prime} \mathrm{E}$ \\
\hline & HKB2 & $50^{\circ} 24^{\prime} \mathrm{N} ; 19^{\circ} 21^{\prime} \mathrm{E}$ \\
\hline & HKFF & $50^{\circ} 21^{\prime} \mathrm{N} ; 19^{\circ} 19^{\prime} \mathrm{E}$ \\
\hline & HKF2 & $50^{\circ} 24^{\prime} \mathrm{N} ; 19^{\circ} 28^{\prime} \mathrm{E}$ \\
\hline & $\mathrm{HKC2}$ & $50^{\circ} 26^{\prime} \mathrm{N} ; 19^{\circ} 29^{\prime} \mathrm{E}$ \\
\hline & HKD1 & $50^{\circ} 31^{\prime} \mathrm{N} ; 19^{\circ} 31^{\prime} \mathrm{E}$ \\
\hline
\end{tabular}
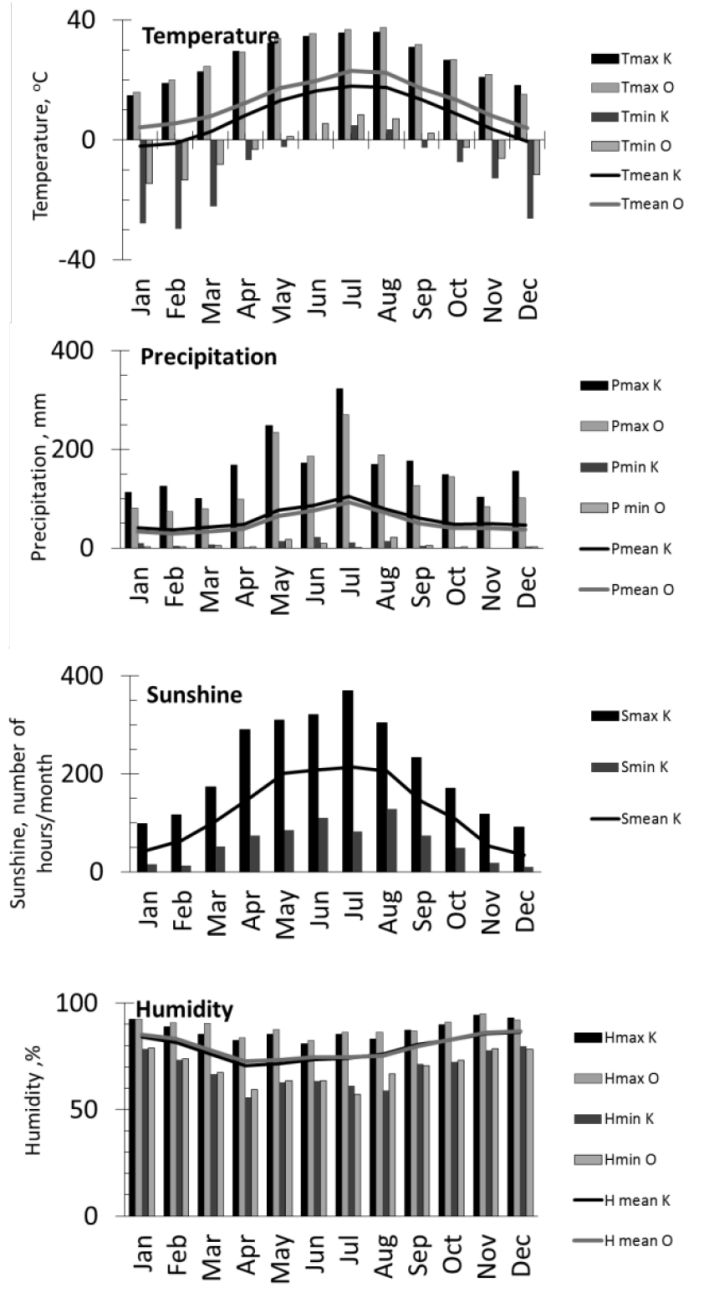

\section{Meteorological data}

Meteorological data were provided by the Polish Institute of Meteorology and Water Management (IMGWPIB). The temperature, humidity, sunshine duration and precipitation data were obtained from the meteorological stations in Katowice and Opole.

The period from 1951 to 2012 was characterised in the regional climate records by the following: an annual mean temperature of approximately $9^{\circ} \mathrm{C}$ (annual range of 6.5 to $10.5^{\circ} \mathrm{C} / \mathrm{yr}$ ), a mean annual precipitation of around $610 \mathrm{~mm}$ (annual range of 360 to $870 \mathrm{~mm} / \mathrm{yr}$ ), mean annual number of sunshine hours of approximately $1530 \mathrm{~h}$ (annual range of 1108 to $1978 \mathrm{~h}$ ), and relative humidity of around $80 \%$ (annual range of $75 \%$ to $86 \%$ ). The lowest precipitation was observed between the mid-1980s and the mid-1990s (Fig. 1).
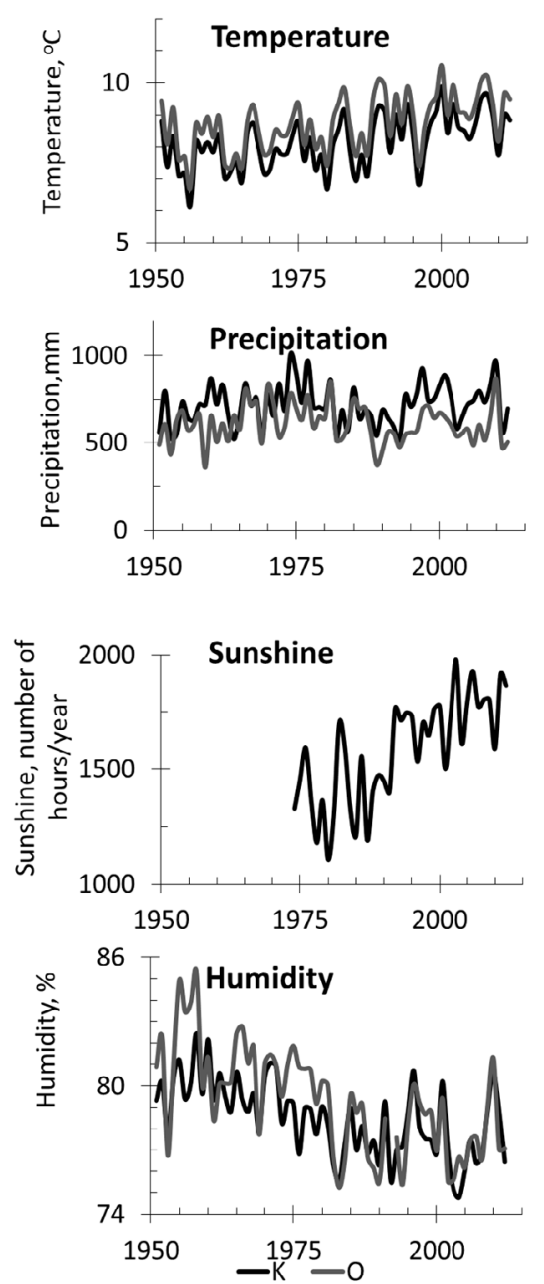

Fig. 1. Meteorological data for the nearest meteorological stations to the investigated area: Opole (O) and Katowice (K): mean temperature, sunshine duration, total rainfall and air relative humidity, for the period 1951-2012). 


\section{The dendrochronological procedures}

The tree-ring widths were measured to the nearest $0.01 \mathrm{~mm}$, and were absolute-dated and rechecked using the COFECHA computer program (Holmes, 1983). The standardisation process of the tree-ring widths eliminates their medium- and long-term variability, and emphasises short-term variations. The tree-ring width series standardisation removes the non-climatic (long-term) trends in growth associated with increasing tree age - the major source of non-stationarity in the time series. Accordingly, the series of the annual sensitivity indices $\left(a s_{i}\right)$ were calculated as follows (Eq. 2.1):

$a s_{\mathrm{i}}=2 \cdot\left(x_{\mathrm{i}}-x_{\mathrm{i}-1}\right) \cdot\left(x_{\mathrm{i}}+x_{\mathrm{i}-1}\right)^{-1}$,

where $x_{i}$ denotes the tree-ring width in year $i$ and $x_{i-1}$ represents the tree-ring width in the previous year (Fritts, 1976).

Then, the site chronologies were determined on the basis of the tree series. The indexed site chronology revealed the short-term variance due to the variation in climatic factors. For each pine stand, the following indicators were calculated: $r_{b t}$ (mean between-tree series correlation), EPS (expressed population signal), SNR (signal-to-noise ratio), and $M S$ (mean sensitivity). The similarity of the short-term incremental reactions of trees in each pine stand was evaluated by calculating the average between-tree series correlation $\left(r_{b t}\right)$. The mean correlation coefficient between all standardised tree-ring series was used for estimating the strength of the chronology signal. It is a statistical quantity representing the common variability in the radial increment of the trees. The mean correlation technique of the indexed series was used for evaluating the chronology signal strength. An advantage of the technique based on correlation versus the analysis of variance (ANOVA) method is that it allows the use of all the indexed series (Briffa and Jones, 1990). The expressed population signal (EPS) facilitates an assessment of the representativeness of the site's chronology (Wigley et al., 1984; Briffa and Jones, 1990). The EPS index quantifies the degree to which the site tree-ring chronology represents the hypothetical (general) ideal chronology, which may in turn be regarded as the macroclimate signal (Wigley et al., 1984). In turn, the $S N R$ index is an expression of the strength of the observed common signal among the trees (Wigley et al., 1984). The change in the tree-ring width was evaluated using the mean sensitivity $(M S) . M S$ is a measure of the inter-annual changes between successive tree-ring widths (Fritts, 1976).

To estimate the dendrochronologically uniform regions for pine, a cluster analysis of the indexed site chronologies (Ward's method and 1-r Pearson's distance) was conducted. The variables were 16 series of correlation coefficients calculated between the indexed site chronology and monthly temperature, precipitation, relative humidity, and duration of direct solar radiation from the previous September to the September in the year of the ring formation. A principal component analysis (PCA) was applied to classify the pine populations. The variables considered were 16 indexed site chronologies. A response function analysis (Fritts, 1976; Holmes, 1983) was used to identify the principal components.

\section{The isotope analysis}

In this study, we assessed the stability of the relationship between tree-ring cellulose $\delta^{13} \mathrm{C}$ and $\delta^{18} \mathrm{O}$ and the climate over the period 1975-2012 for Scots pine. The chronologies were based on a pooled-ring approach, with 10 trees per 3 sites (LAP in the LA region, ZKC in the KK region, and HKF2 in the HK region). The absolutedated annual tree rings were manually separated as thin slivers, and then pooled (equally weighted per tree) and homogenised. The $\alpha$-cellulose samples were extracted using Green's method (1963), with further modifications (Pazdur et al., 2007; Sensuła and Wilczyński, 2017) in the Silesian University of Technology, Poland.

The carbon and oxygen stable isotope compositions were measured by IRMS (Isoprime, GV Instruments, Manchester, UK) in the Institute of Physics, the Silesian University of Technology, Poland. We reported the isotope values in the delta notation as follows (Eq. 2.2):

$\delta=\left(R_{\text {sample }} / R_{\text {standard }}-1\right) \cdot 1000, \%$ o

for carbon $\left(\delta^{13} \mathrm{C}\right)$ and oxygen $\left(\delta^{18} \mathrm{O}\right)$ in respect of the international standard, which was Vienna Pee Dee Belemnite (VPDB) for carbon and Vienna Standard Mean Ocean Water (VSMOW) for oxygen. $R_{\text {sample }}$ and $R_{\text {standard }}$ denote the molar fractions of ${ }^{13} \mathrm{C} /{ }^{12} \mathrm{C}$ and ${ }^{18} \mathrm{O} /{ }^{16} \mathrm{O}$ for the sample and the standard, respectively. The calibration was done using an internal standard (C-3 and C-5, IAEA for $\delta^{13} \mathrm{C}$ and $\mathrm{C}-3$, IAEA for $\delta^{18} \mathrm{O}$ ).

To test the stability of the climate-isotope relationship over the period 1975-2012, we performed correlation analyses. The analysis of the temporal stability of the climate proxy was based on forward evolutionary intervals (base length: $t_{l}=26$ years) in the bootstrap (Biondi, 1997) correlation function. The start year in this method is fixed. Using the evolutionary intervals gives the possibility to calculate a progressively greater number of years $\left(t_{i+1}=t_{i}+1\right)$ for a correlation-coefficient calculation. To calculate $i W U E$ on the basis of $\delta^{13} \mathrm{C}$ in plants we used the formula according to Farquhar and Lloyd (1993); McCarroll and Loader (2004), Saurer et al. (2004) and and Silva and Horwath (2013) Eqs. 2.3-2.5:

$$
\begin{aligned}
& \Delta^{13} C=\frac{\delta^{13} c_{\text {air }}-\delta^{13} c_{\text {plant }}}{1+\frac{\delta^{13} C_{\text {plant }}}{1000}} \\
& \Delta^{13} C=a+(b-a) c_{i} / c_{a} \\
& i W U E=\frac{A}{g}=c_{a}\left[1-\frac{c_{i}}{c_{a}}\right] 0.625
\end{aligned}
$$

where $c_{\mathrm{i}}$ is intercellular $\mathrm{CO}_{2}$ concentration, $c_{a}$ is ambient $\mathrm{CO}_{2}$ concentration, a $(\mathrm{ca} .4 .4 \%)$ is the discrimination against ${ }^{13} \mathrm{CO}_{2}$ during $\mathrm{CO}_{2}$ diffusion through stomata, and $\mathrm{b}$ 
(ca. 27\% ) is the discrimination associated with carboxylation.

\section{RESULTS}

\section{Dendrochronology}

The indexed site chronologies showed a high similarity of year-on-year processes and indicated the strong dynamics of the size of the radial growth of pines in various sites in certain years (Fig. 2).

The $\mathrm{r}_{\mathrm{bt}}$ indices ranged from 0.399 to 0.521 (Table 2). This indicated the various strengths of the short-term signal in individual chronologies. All EPS values of the site chronologies were greater than 0.85 . The EPS and $S N R$ values of the site chronologies indicated a strong climatic signal, which in turn indicated a high representativeness of the indexed site chronologies. The mean sensitivity of all the tree-ring widths of the pine partial populations ranged from 0.158 to 0.308 . Therefore, we found that throughout the study period particular pine populations showed strongly differentiated sensitivity to shortterm environmental factors. The lowest sensitivity was exhibited by the pines from KK. The variance explained by the first eigenvector of the indexed ring width series was different, and ranged from $36 \%$ to $66 \%$, indicating a high homogeneity of growth reactions of the pines in most sites (Table 2).

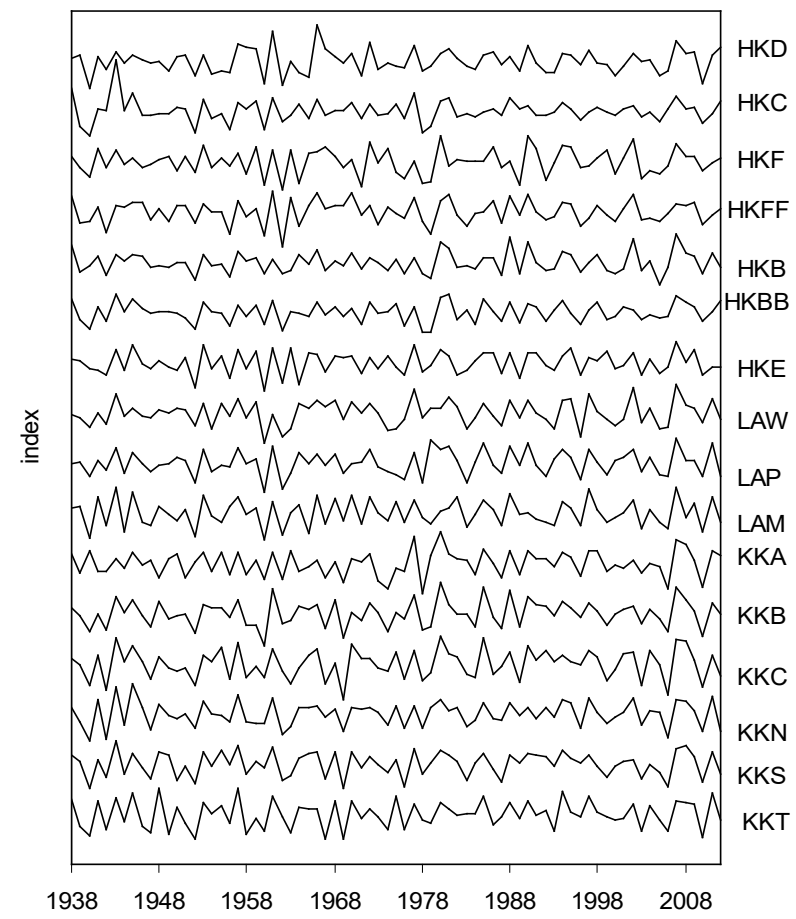

Fig. 2. Indexed site chronologies of pine stands.
The indexed site chronologies were correlated with each other within a common period from 1951 to 2012. The similarity between site chronologies decreased with distance, and was high within each of the considered regions; further, it was often high between sites from various regions (Fig. 3). This grouping exhibited the regional locations of the pine sites and suggested a division of the tested area into three dendrochronologically similar regions: KK, LA, and the nearby HK. In all cases, the correlation was significant $(p<0.01)$.

To identify the reaches of the dendrochronologically uniform regions more clearly, a PCA was used. The first component (PC1) accounted for $65 \%$ of the variance

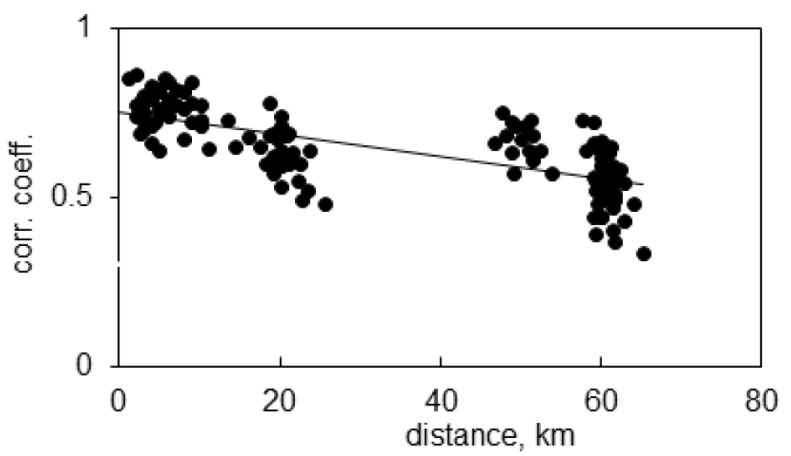

Fig. 3. The correlation coefficients between the indexed site chronologies and the distance between pine sites.

Table 2. The statistics of 16 tree-ring-site collections for the period 1951-2012 (MS: mean sensitivity, $\mathrm{rbt}_{\mathrm{bt}}$ : mean between-tree series correlation, EPS: expressed population signal, SNR: signal-to-noise ratio, Var.pC1: variance in the first component).

\begin{tabular}{lcccccc}
\hline & $\begin{array}{c}\text { No. of } \\
\text { trees } \\
\text { and } \\
\text { cores }\end{array}$ & $r_{b t}$ & EPS & SNR & MS & Var.PC1 \\
\hline HKE & 20 & 0.279 & 0.886 & 7.7 & 0.255 & 37 \\
\hline HKBB & 20 & 0.322 & 0.905 & 9.5 & 0.219 & 47 \\
\hline HKB & 20 & 0.445 & 0.941 & 16.0 & 0.236 & 60 \\
\hline HKFF & 20 & 0.300 & 0.896 & 8.6 & 0.283 & 43 \\
\hline HKF & 20 & 0.334 & 0.909 & 10.0 & 0.286 & 45 \\
\hline HKC & 20 & 0.545 & 0.960 & 23.9 & 0.226 & 66 \\
\hline HKD & 20 & 0.227 & 0.855 & 5.9 & 0.265 & 36 \\
\hline LAW & 20 & 0.518 & 0.953 & 21.5 & 0.284 & 64 \\
\hline LAP & 20 & 0.399 & 0.930 & 13.3 & 0.285 & 51 \\
\hline LAM & 20 & 0.514 & 0.954 & 21.2 & 0.308 & 63 \\
\hline KKA & 20 & 0.361 & 0.918 & 11.3 & 0.204 & 49 \\
\hline KKB & 20 & 0.421 & 0.935 & 14.5 & 0.197 & 54 \\
\hline KKC & 20 & 0.355 & 0.916 & 11.0 & 0.201 & 48 \\
\hline KKN & 20 & 0.319 & 0.903 & 9.4 & 0.158 & 46 \\
\hline KKS & 20 & 0.424 & 0.936 & 14.7 & 0.191 & 55 \\
\hline KKT & 20 & 0.371 & 0.922 & 11.8 & 0.210 & 50 \\
\hline & & & & & &
\end{tabular}


among the site chronologies. All the indexed site chronologies correlated highly with PC1 (Fig. 5). Since 17 pine chronologies were clustered tightly with $\mathrm{PC} 1$, a high common variance between all the pine populations was obtained. The second component (PC2) accounted for $12 \%$ of the variance among pine chronologies. PC2 divided the pine populations into three regional groups (Fig. 4).

We assumed that any characteristic incremental rhythm of pines in each region would be shaped by climatic factors. To test this, we correlated the indexed site chronologies with the climatic parameters. Thus, we obtained a series of correlation coefficients for each pine population (Fig. 5). The cluster analysis divided the correlation coefficient series into three identical groups, the same as in the case of the analysis of the indexed site chronologies (Fig. 4). The first cluster included the pine populations from the KK region, the second had pines from LA, and the third consisted of populations from HK (Fig. 4). Therefore, the incremental rhythm of pines differentiated the climatic factors and the question remains as to which elements of the climate determined this differentiation. Therefore, a PCA of the indexed site chronologies was conducted.

The variability of climate conditions from year to year mainly determined the short-term variance of the radial increment of the trees. The first two components described the climate elements which had a significant impact $(77 \%)$ on the radial-growth variability of the pines. The climate factors described by $\mathrm{PC} 1$ and PC2 were identified by a correlation-function analysis (Fig. 6). PC1 integrated the pine chronologies and correlated $(p<0.05)$ with the monthly relative humidity, precipitation, and sunshine duration of the previous September.
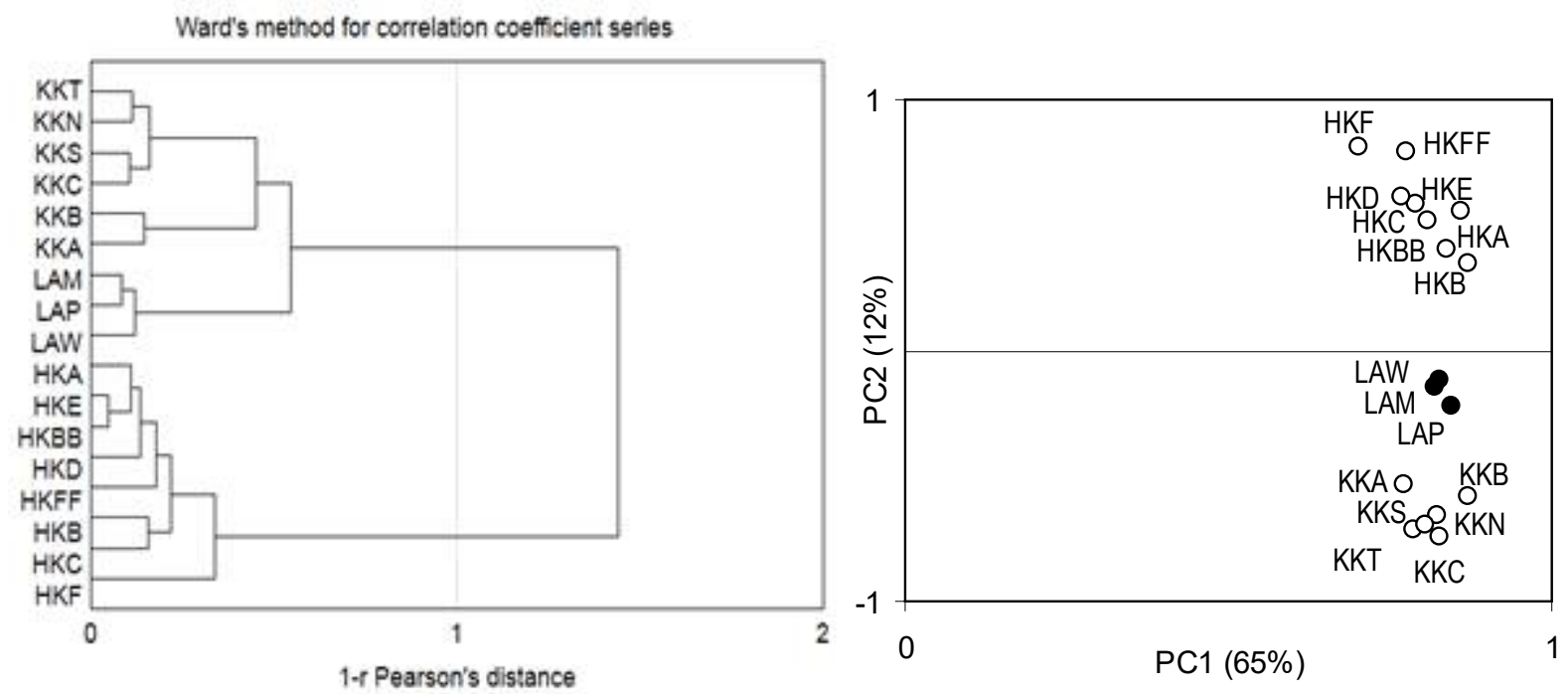

Fig. 4. The results of the cluster analysis of 16 correlation-coefficient series (left) calculated between the indexed site chronologies and 26 climatic parameters (see Fig. 5) and the location of 16 indexed site chronologies to the loadings of the first and second components (right).

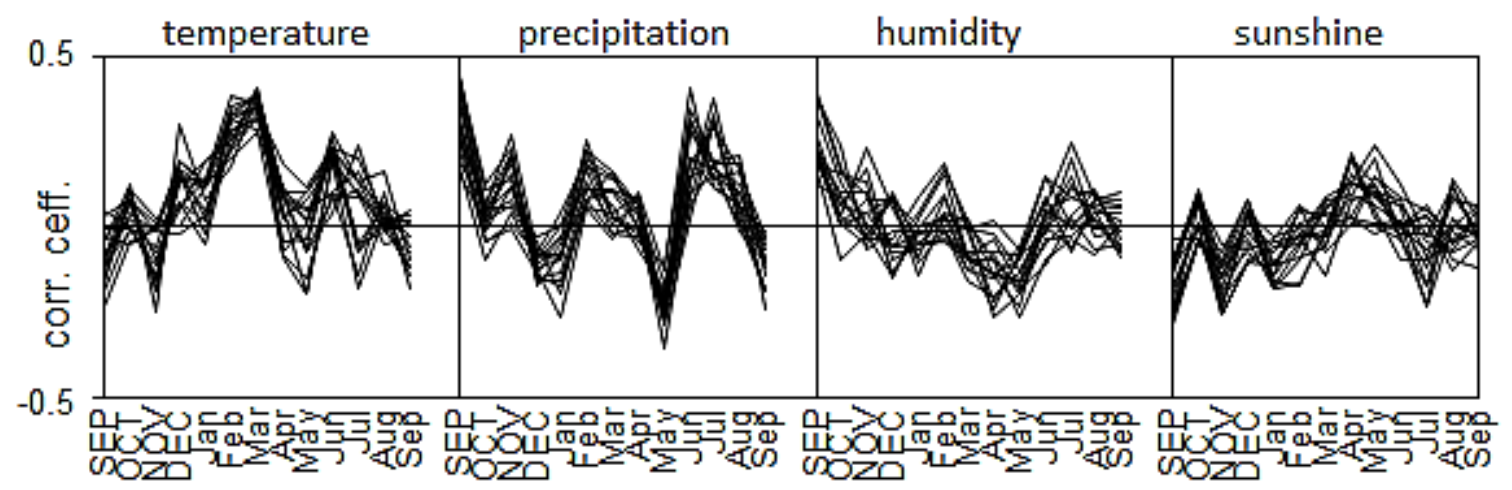

Fig. 5. The correlation coefficients calculated between the indexed site chronologies and site monthly values of temperature, precipitation, relative humidity, and sunshine duration (correlation-coefficient series) from the previous September (SEP) to current September (Sep). 


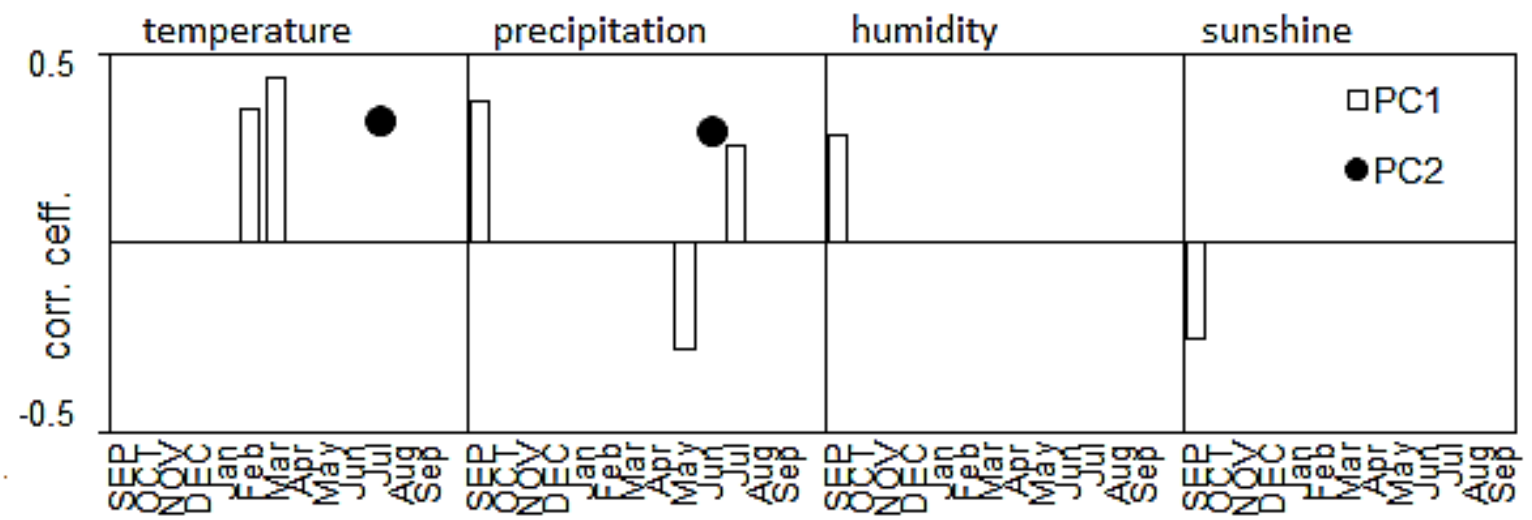

Fig. 6. Significant correlation coefficients (at the 95\% level) calculated between PC1, and PC2 and monthly values of temperature, precipitation, relative humidity, and sunshine duration from the previous September (SEP) to the current September (Sep).

The first component also correlated with the February and March temperatures and the May and July precipitation values of the year of the ring formation. The climatic factors described by PC1 had a similar and significant impact on the radial growth of all Scots-pine populations. PC2 differentiated the indexed site chronologies and correlated significantly with the monthly precipitation of June and the July temperatures (Fig. 6). The pines in each region reacted differently to these two factors. Scots pine from HK was more sensitive to low temperatures in July and low precipitation in June in the year of the ring formation.

\section{General trends in $\delta^{13} \mathrm{C}$ and $\delta^{18} \mathrm{O}$}

The pattern of the spatial and temporal variability of $\delta^{13} \mathrm{C}$ and $\delta{ }^{18} \mathrm{O}$ in the samples extracted from the annual tree rings of pines growing in the three regions, namely LA, HK, and KK, is illustrated in Fig. 7.

The average value of pine $\delta^{13} \mathrm{C}$ in each sampling site was approximately $23.9 \%$, whereas the average value of pine $\delta^{18} \mathrm{O}$ in each sampling site was approximately 29.7\%o. However, different trends in $\delta^{13} \mathrm{C}$ and $\delta^{18} \mathrm{O}$ were observed in each sampling site. The typical decline in $\delta^{13} \mathrm{C}$ due to the global atmospheric trend could be observed after 1990. It is possible that the typical decline in $\delta^{13} \mathrm{C}$ prior 1990s might have been masked by another factor, or factors. In $\mathrm{KK}$, the pine $\delta^{13} \mathrm{C}$ series data ranged from $-24.6 \%$ to $-23.2 \%$ (uncorrected) and from $-23.1 \%$ to $-21.9 \%$ (corrected); in LA, the pine $\delta^{13} \mathrm{C}$ series data ranged from $-24.4 \%$ to $-23.1 \%$ (uncorrected) and from $-23.4 \%$ to $-21.6 \%$ (corrected); and in $\mathrm{HK}$, the pine $\delta^{13} \mathrm{C}$ series data ranged from $-25.3 \%$ to $-22.9 \%$ (uncorrected) and from $-23.6 \%$ to $-21.5 \%$ (corrected). The mathematical correction for the atmospheric $\delta^{13} \mathrm{C}$ trend to remove the effect of the changes in $\delta^{13} \mathrm{C}$ was carried out using a dataset of high-frequency measurements (McCarroll and Loader, 2004; McCarroll et al., 2009; NOAA). This correction considered the $\mathrm{CO}_{2}$ contribution by fossil fuels to
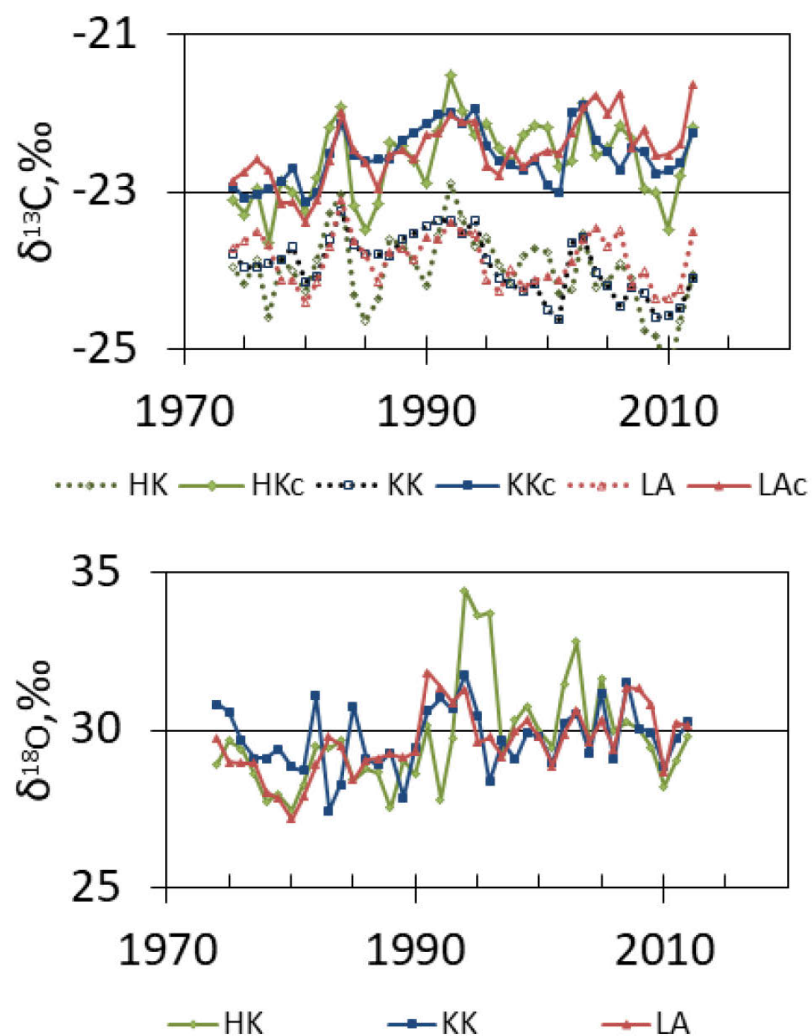

Fig. 7. Trends of $\delta^{13} \mathrm{C}$ (measured value: $H K, K K, L A$ and corrected values: $H K c, K K c, L A c)$ and $\delta^{18} \mathrm{O}$ in $\alpha$-cellulose samples extracted from pines growing in three forests in $H K, K K$, and $L A$.

the European air. This correction increased the range of $\delta^{13} \mathrm{C}$ and reduced the decline observed in the previous decades (Rinne et al., 2010). Further, the $\delta^{13} \mathrm{C}$ and $\delta^{18} \mathrm{O}$ values of the $\alpha$-cellulose samples extracted from the pine trees growing in the three forests show a significant correlation between them $(n=39)$, which confirms the simi- 
larity in the trees' response to the changes in the ecosystem (Table 3). However, in the case of the HK and KK series, the correlation between the $\delta^{18} \mathrm{O}$ values in the two chronologies was the lowest, but it was still at a significant level. Since the late 1990s, a close accordance between all the three oxygen-isotopic chronologies was observed (Fig. 7).

Table 3. The correlations between the values of $\delta^{13} \mathrm{C}$ for three forests and the correlations between the values of $\delta^{18} \mathrm{O}$ for three forests: Dąbrowa Górnicza near Huta Katowice (HK), Kędzierzyn-Kożle (KK), and Łaziska (LA) (all values are significant at $p<0.05$ ).

\begin{tabular}{ccccc}
\hline$\delta^{13} \mathrm{C}$ & site & HK & KK & LA \\
\cline { 2 - 5 } & HK & - & 0.61 & 0.56 \\
& KK & 0.61 & - & 0.66 \\
& LA & 0.56 & 0.66 & - \\
\hline & & & & \\
\hline$\delta^{180}$ & site & HK & KK & LA \\
\cline { 2 - 5 } & HK & - & 0.34 & 0.51 \\
& KK & 0.34 & - & 0.52 \\
& LA & 0.51 & 0.52 & - \\
\hline
\end{tabular}

\section{The correlation of the $\delta^{13} \mathrm{C}$ and $\delta^{18} \mathrm{O}$ series}

In certain periods, a significant positive correlation between $\delta^{13} \mathrm{C}$ and $\delta^{18} \mathrm{O}$ was found, whereas in other time periods, this correlation was not significant (Fig. 8b-8d). With the KK pine, the highest significant positive correlation $(r=0.77)$ was found for the period 1991-2000. In contrast, in LA, the highest significant positive correlation was found for two periods of time: 1975-1990 ( $r=$ $0.83)$ and 1991-2000 $(r=0.82)$. However, in the case of the HK series, a significant positive correlation $(r=0.74)$ was found for the period 2001-2012, whereas no significant correlation was found in KK for the period 1975$1990(r=0.28)$ and 2001-2012 $(r=0.47)$, in LA for the period 2001-2012 $(r=0.064)$, in HK for two periods of time: $1975-1990(r=0.18)$ and $1991-2000(r=0.37)$, respectively. According to Scheidegger et al. (2000), the combined analyses of carbon and oxygen isotopes in tree rings can suggest whether stomatal conductance or photosynthesis (Fig. 8a) contribute the most to the variation of $i W U E$ in response to elevated $\mathrm{CO}_{2}$ levels (Saurer et al., 2004).

Across all the sites, elevated anthropogenic carbondioxide emission increased the ${ }^{13} \mathrm{C}$-derived water-use efficiency on average by $40 \%$ (Fig. 9). Further, a positive land-surface temperature anomaly- $i W U E$ relationship was observed. The elevated $\mathrm{CO}_{2}$ increased the $i W U E$ of the forests (Fig. 9). a)

\begin{tabular}{|l|l|l|l|l|l|l|l|l|}
\hline$\delta^{13} \mathrm{C}$ & $\uparrow$ & $\uparrow$ & $\uparrow$ & $\downarrow$ & $\downarrow$ & $\downarrow$ & $*$ & $*$ \\
\hline$\delta^{18} \mathrm{O}$ & $\uparrow$ & $*$ & $\downarrow$ & & $*$ & $\downarrow$ & $\uparrow$ & $\downarrow$ \\
\hline $\mathrm{A}$ & $*$ & $\uparrow$ & $\uparrow$ & $\uparrow$ & $\downarrow$ & $*$ & $\downarrow$ & $*$ \\
\hline $\mathrm{g}$ & $\downarrow$ & $*$ & $*$ & $*$ & $*$ & $\uparrow$ & $*$ & $\uparrow$ \\
\hline
\end{tabular}

b)

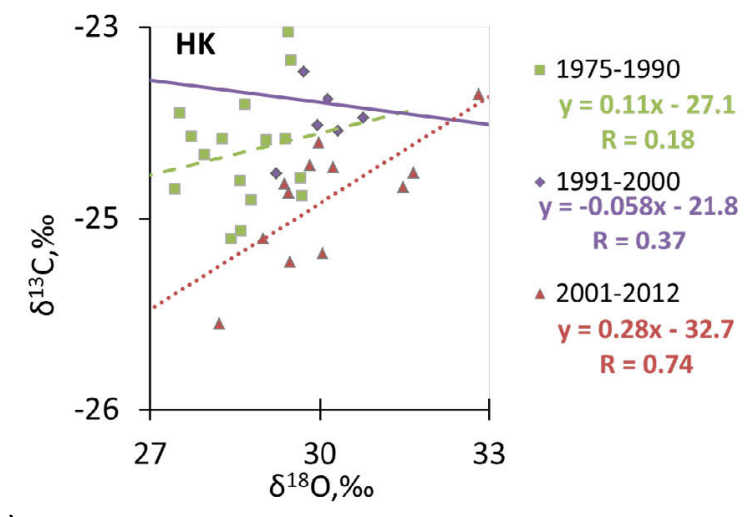

c)

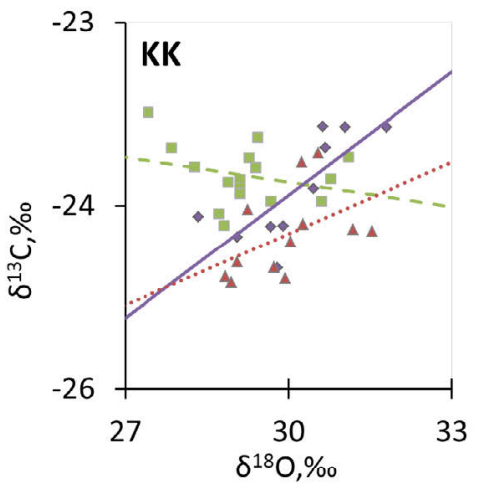

- 1975-1990

$y=-0.068 x-21.8$ $R=0.28$

-1991-2000

$y=0.34 x-34.01$

$\mathrm{R}=0.77$

4 2001-2012

$y=0.20 x-30.1$

$R=0.47$

d)

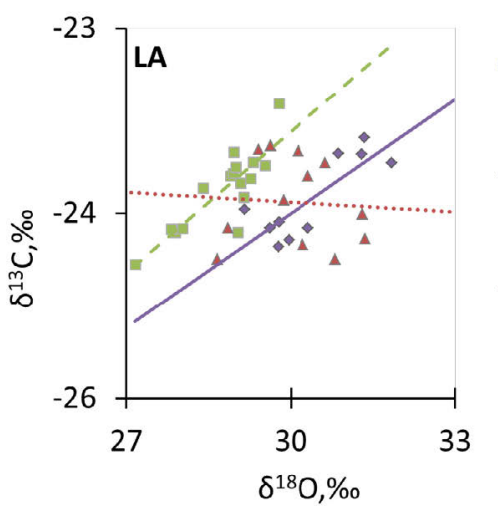

- 1975-1990

$y=0,38 x-34,8$ $R=0.83$

- 1991-2000

$y=0.31 x-33.2$

$\mathrm{R}=0.82$

4 2001-2012

$y=-0.027 x-23.1$

$\mathbf{R}=0.064$

Fig. 8. (a) Theoretical scenarios (Scheidegger et al., 2000) for the interaction between the stomatal conductance $(\mathrm{g})$ and photosynthesis (A) and isotope composition of plants; (up- or downward arrows represent increasing or decreasing values, *indicates insignificant changes) and (b) a comparison of the $\delta^{13} \mathrm{C}$ and $\delta^{18} \mathrm{O}$ series for the investigated sites: (b) HK, (c) KK, and (d) LA for three periods of time: since 19571990 prior to significant modernisation in the factories, since 19912000, when was a significant modernisation in the factories; since 2001 - the period when the pro-ecological strategy was implemented in each factory due to changes in the Polish law. 
a)

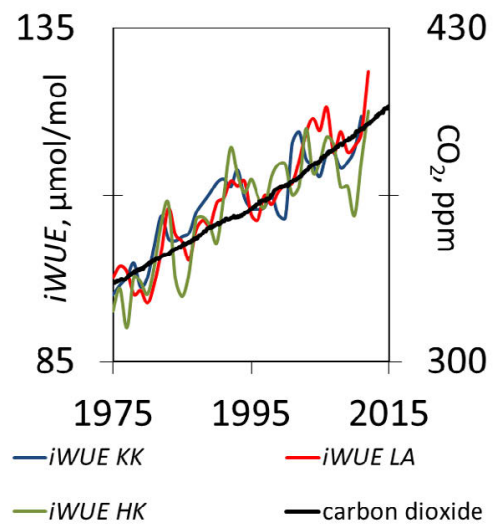

b)

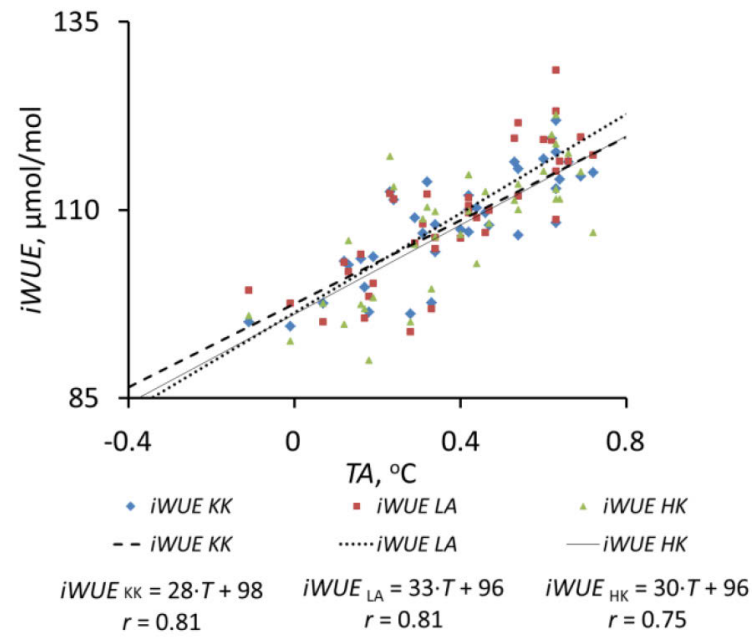

Fig. 9. (a) Increased intrinsic water-use efficiency (iWUE) in pines during increases in $\mathrm{CO}_{2}$ emissions into the atmosphere (in the period from 1975 to 2012), (b) the correlations between intrinsic water-use efficiency (IWUE) and a land surface temperature anomaly (TA) (the deviation from the longterm average, NOAA).

\section{The climate-carbon and oxygen-stable isotope compo- sition relationships}

The resulting isotopic chronologies were correlated against meteorological parameters from the nearest meteorological station in Opole (for KK) and in Katowice (for LA and HK) (Fig. 10). The presented analyses indicate the parameters (annual climatic factors) with which the isotopic composition of pine achieved the highest correlation (at the 95\% significance level) (Fig. 10a). It describes how climate factors impact on the isotopic composition of trees. In times of relatively high annual temperature and increased insolation, $\delta^{13} \mathrm{C}$ increases, whereas a relatively high amount of precipitation and an increase in humidity decrease the $\delta^{13} \mathrm{C}$ in the trees.

In the case of $\delta^{13} \mathrm{C}$, the chronologies from each site (Fig. 10b) were positively correlated with the mean temperature and sunshine in summer, and negatively correlated with the humidity in spring and summer. An analysis revealed some significant similarities in the relationships between climatic factors (such as the temperatures in July and August; sunshine in July; and humidity in April, July, August, and September), and the carbon isotopic composition of the pines growing in each investigated area. These implied that the response of trees to changes in climatic parameters can only be recorded in some months in line with the variations in the isotopic composition of the pines growing, whereas the isotopic response to changes in weather conditions in other months can be varied.

On the other hand, the pines growing in the KK region differed in their isotopic response to humidity. A relationship between humidity and the carbon isotopic composition revealed a high correlation in spring and summer, and the influence of the humidity of the previ- ous year could be noted. Further, the response of the pines to precipitation was different in different sites; however, some similarities were observed for the pines growing in the $\mathrm{HK}$ and $\mathrm{KK}$ regions, whereas a relatively high insolation increases $\delta^{18} \mathrm{O}$. The pines growing in LA showed the highest correlations and the strongest climateoxygen isotopic composition of pine.

In the case of $\delta^{18} \mathrm{O}$, the values in the chronologies from each site (Fig. 10b) were positively correlated with the sunshine during the entire vegetation period and the temperature in July. A strong and significant negative correlation was observed between humidity and the oxygen isotopes only in the pines growing in KK and LA. Only the pines growing in LA showed a negative significant correlation with the precipitation in August.

\section{The stability of the climate-isotope relationship}

To test the stability of the climate-isotope relationship over the period 1975-2012, we performed correlation analyses, and Fig. 11 presents the significant correlation coefficients for the studied months (the previous September to the current September) as a function of the investigated evolutionary intervals - a progressively greater number of years is used for correlation-coefficient calculation (X axis). The start year in this method is fixed, and only the end year of the interval is presented on the $\mathrm{X}$ axis. For the $\delta^{13} \mathrm{C}$ and $\delta^{18} \mathrm{O}$ pines, the correlations with temperature were consistently positive for the current growing-season temperatures (mainly April, June, July, and August) (Fig. 11). Further, the temperature in January was important for determining the $\delta^{13} \mathrm{C}$ and $\delta^{18} \mathrm{O}$ signals, but these correlations were temporally unstable and weak. 
a)

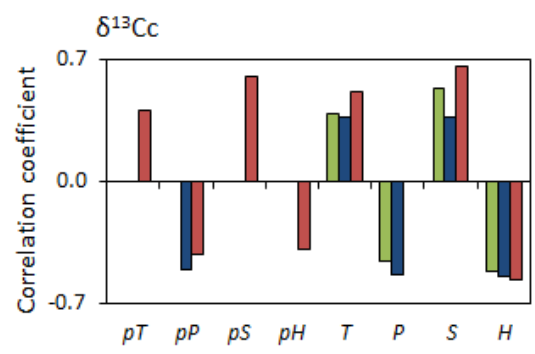

b)

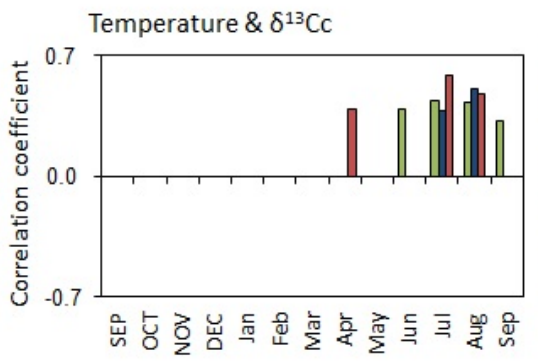

Precipitation \& $\delta^{13} \mathrm{Cc}$

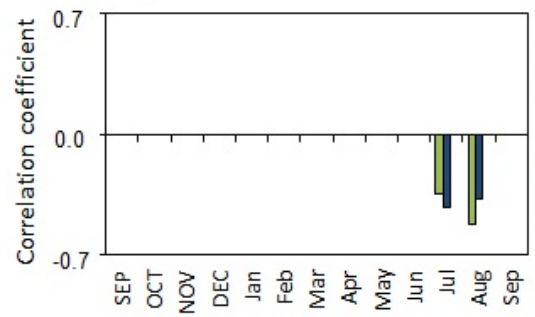

Sunshine \& $\delta^{13} \mathrm{CC}$

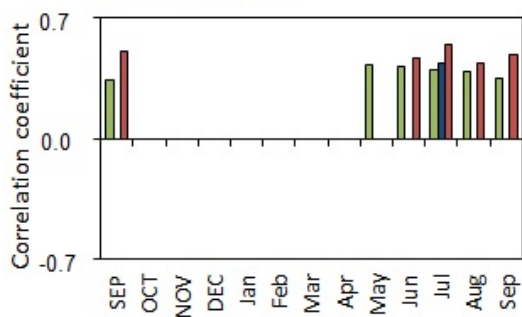

Humidity $\& \delta^{13} \mathrm{Cc}$

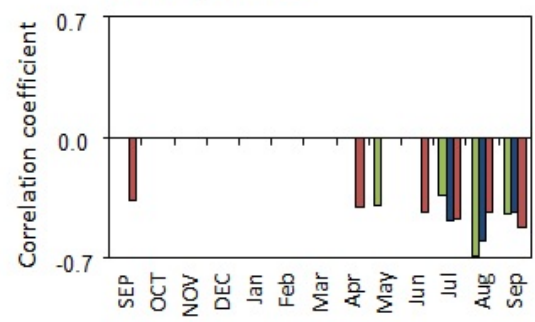

口HK घKK ロLA

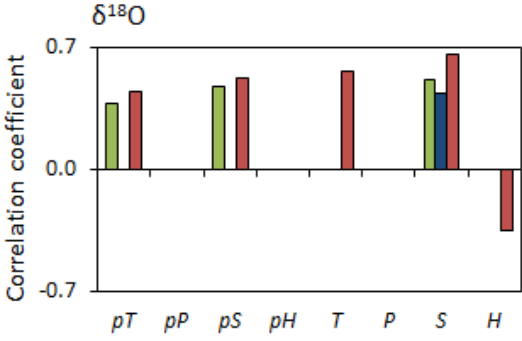

口HK $\square$ KK 口LA

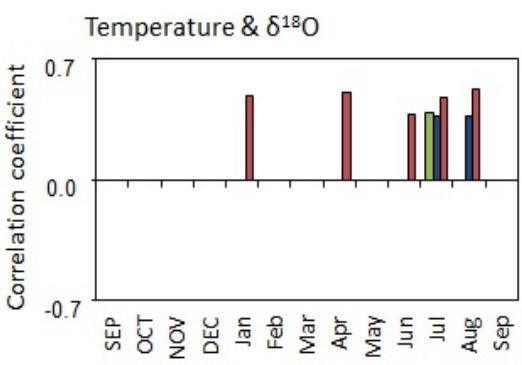

Precipitation \& $\delta^{18} \mathrm{O}$

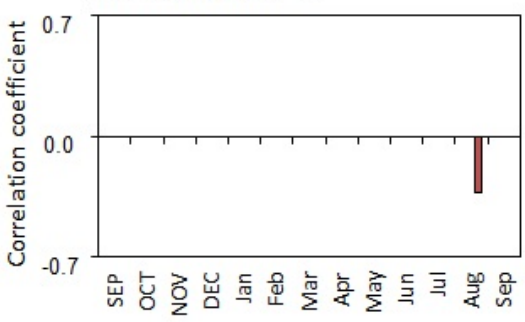

Sunshine $\& \delta^{18} \mathrm{O}$

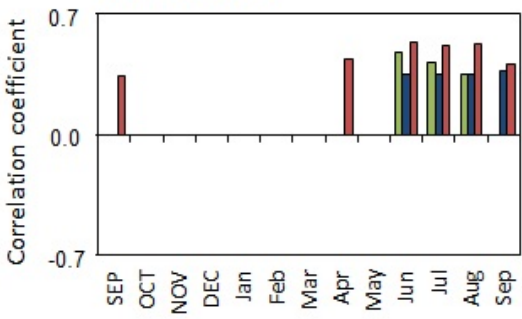

Humidity $\& \delta^{18} \mathrm{O}$

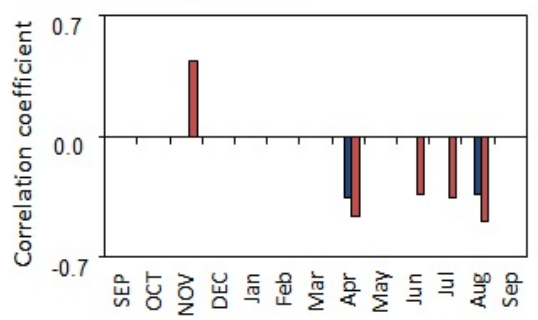

口HK घKK घLA

Fig. 10. The correlation coefficients between $\delta^{13} C_{c}$ (corrected values) and $\delta^{18} \mathrm{O}$ in $\alpha$-cellulose samples from three forests in $H K, K K$, and $L A$, and (a) annual climatic factors: mean temperature $(\mathrm{T})$, sum of precipitation $(\mathrm{P})$, sunshine $(\mathrm{S})$, and relative humidity $(\mathrm{H})$ from previous year $(\mathrm{p})$ and current year and (b) monthly climatic factors: mean temperature, sum of precipitation, sunshine, and relative humidity; significance level = 95\%. 
a)

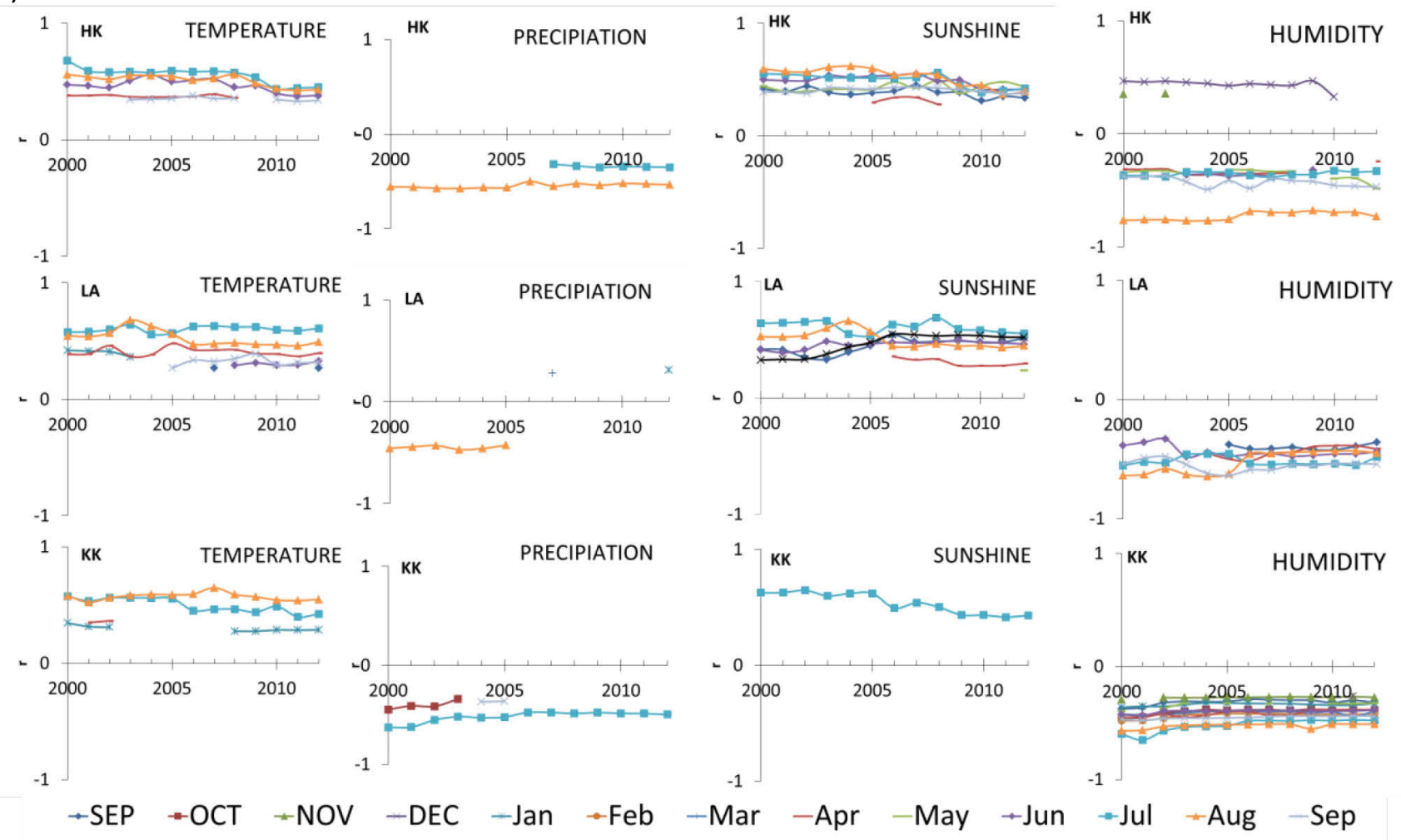

b)

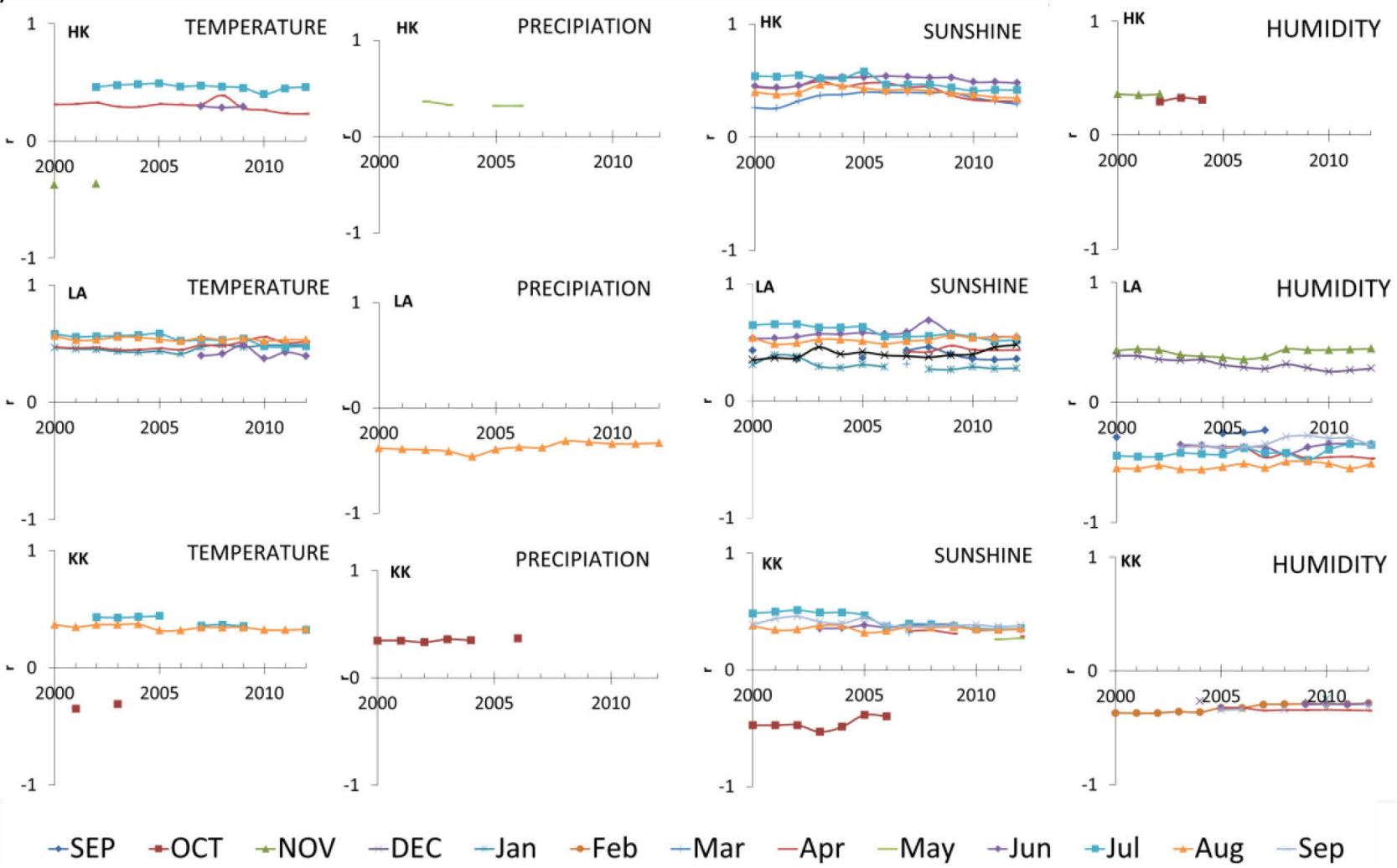

Fig. 11. Forward evolutionary interval correlations (bootstrap correlation function) between monthly climate factors (temperature, precipitation, duration of sunshine, humidity) and carbon (a) and oxygen (b) the stable isotopic composition of tree-ring cellulose for the period 1975-2012, for the September of the previous year to the September of the current year, using a base length of 26 (plotted against the last year of the period); significance level $=95 \%$. 
For the $\delta^{13} \mathrm{C}$ pines, correlations with the precipitation amount were negative for summer (July or August). For the pines growing in LA, the correlations with precipitation were temporally unstable. The $\delta^{18} \mathrm{O}$ correlations with precipitation were temporally unstable in $\mathrm{KK}$ and $\mathrm{HK}$, whereas in LA the negative correlation with precipitation in August was strong and stable. Correlations between sunshine and both isotopes were mostly positive for the growing-season sunshine. In general, for $\delta^{13} \mathrm{C}$, sunshine in July was significant for determining the $\delta^{13} \mathrm{C}$ signal for all the three relationships studied, and sunshine in summer (June-September) was important for determining the $\delta^{13} \mathrm{C}$ signal in LA and HK. For $\delta^{18} \mathrm{O}$, sunshine in summer (June-September) was important for determining the $\delta^{18} \mathrm{O}$ signal in all the investigated sites. In contrast, for pines growing in LA and HK a strong significant correlation was observed with the sunshine spread over much of a given year. The significant correlations of $\delta^{13} \mathrm{C}$ with humidity were predominantly negative for the summer months (June-September) in all the investigated sites. The sign of the correlation in December changed from negative (in LA and $\mathrm{KK}$ ) to positive (in $\mathrm{HK}$ ). The most consistent significant correlations with humidity determined the $\delta^{13} \mathrm{C}$ signal in pines growing in LA and HK. For $\delta^{18} \mathrm{O}$ pines, the correlations with humidity were unstable in $\mathrm{HK}$ and $\mathrm{KK}$, whereas in LA, the correlation was stronger and more stable. The significant correlations of $\delta^{18} \mathrm{O}$ with humidity were positive for the months of the previous year (November-December) and negative for the months of the current year (June-September). Relationships between climate and the isotopic composition exhibited spatiotemporal diversity. A combination of parameters can impact on the isotopic composition of pine (Leegood and Edwards, 1996; McCarroll and Loader 2004; Sensuła and Wilczyński, 2017).

\section{DISCUSSION}

\section{The climate-tree-ring width relationship}

The similarity of the incremental reactions (year-onyear) of pines from various sites was relatively high. Therefore, a supra-regional factor was determined. We assumed that this was a climate factor. The answer was provided to us by the PCA carried out later in this study.

The mean correlation coefficient, expressed population signal, signal-to-noise ratio, and variance in the first component calculated for each pine population, indicated a strong climatic signal in the indexed site chronologies. The mean sensitivity implied a strongly differentiated susceptibility to short-term environmental factors. One such factor that changed from year to year was climatic conditions. The variance explained by the first eigenvector indicated a high similarity of the radial growth reactions of the pines.

The greatest distance between the pine sites was 66 $\mathrm{km}$. The conifer chronologies in North America correlated at the $99 \%$ level over a distance of $1000 \mathrm{~km}$ (Cropper and Fritts, 1982), and in Spain over a distance of $500 \mathrm{~km}$ (Richter et al., 1991). In Poland, sufficient cross-dating quality between Douglas fir chronologies could be expected within an average range of about $800 \mathrm{~km}$ (Feliksik and Wilczyński, 2004).

The variability of climate conditions from year to year determined the short-term variance of the radial increment of trees. The first two components described the climate elements which had a significant impact on the radial growth variability of pines. The climatic factors as described by PC1 had a similar and significant impact on the radial growth of all Scots-pine populations. PC2 differentiated pine sites. The pines in each region reacted differently to factors described by the second component.

Our results implied that high July precipitation and high winter temperatures were beneficial to the radial growth of the pines. Under drought stress in the vegetation season, the trees had relatively low cambial activity, thereby reducing the cambial division and cell-wall thickening (Irvine et al., 1998; Cinnirella et al., 2002; Piovesan et al., 2008).

However, low precipitation in May had a positive impact on the radial growth of the pines. Low precipitation indicates low cloudiness which does not limit solar radiation. Therefore, we concluded that solar radiation could stimulate cambium activity.

The temperature in winter was the main limiting factor for the activity of pines. In late winter and early spring, a relatively high air temperature initiated physiological and biochemical processes faster, and caused vascular cambium activation earlier (Gricar et al., 2006; Rossi et al., 2008; Balanzategui et al., 2017). In cold regions, the tree-ring growth of trees was mainly limited by the summer temperature (Lindholm et al., 2000; Helama et al., 2002, 2005; Macias et al., 2004; Wilczyński and Szymański, 2015).

We have observed that a wet and cloudy previous September had a positive impact on the radial increment of pines in all sites. Such weather conditions are favourable for the carbohydrate accumulation by trees used in the next year to build wood cells (Hoch et al., 2003; Vaganov et al., 2006).

Different effects on the growth of the pine trees from individual regions (KK, LA, and $\mathrm{HK}$ ) were observed in the cases of the precipitation in June and the July temperature. Scots pine from HK was more sensitive to a low temperature in July and a low precipitation in June in the year of the ring formation. This could be attributed to the cooler and drier climate in this region.

\section{The climate-isotope composition relationship}

The correlation analysis yielded mostly expected results. Positive relationships with temperature and sunshine, and negative relationships with precipitation and humidity, were observed for $\delta^{13} \mathrm{C}$. In contrast, a positive relationship with temperature and a negative relationship with humidity were observed for $\delta^{18} \mathrm{O}$. However, it has 
been noted that the correlations showed certain temporal instability differently in each of the investigated sites. The current growing-season climate (from April to September) dominated the $\delta^{13} \mathrm{C}$ and $\delta^{18} \mathrm{O}$ signals, despite the significant relationships found for several months from the previous year. As far as $\delta^{18} \mathrm{O}$ is concerned, there might be a depth-dependent temporal offset resulting from an effective uptake of the soil water by the roots (Saurer et al., 1997b). The isotope-climate relationships can also be affected by a change in the relationship between the climate variables (Edwards et al., 2000).

The isotopic composition of pines growing in LA has been the most sensitive to climate changes, and the chronologies for both elements reflect the largest number of climatic parameters.

The differences in the relationship between climate and the carbon and oxygen stable isotope composition of the trees growing in different areas can be attributed to the effect of the masking of the climatic signal by pollution (Leonelli et al., 2012; Boettger et al., 2014).

The climate-isotope composition of tree-ring cellulose relationships is not stable over time. The previous analysis shows that from 1950 to 2000 , the correlation coefficients between $\delta^{13} \mathrm{C}$ and the climate factors in the Niepolomice Forest (Poland) were not stable over the entire studied period (Sensuła et al., 2011). Several studies have also shown changes in the trees' response to the climate forces in recent decades, such as reduced sensitivity to a certain climatic factor and increased sensitivity to another; for example Boettger et al., (2014) analysed the climate sensitivity of carbon isotope signatures in treering cellulose in Germany, and reported a reduction in the climate sensitivity of $\delta^{13} \mathrm{C}$. Several tree-ring studies have also concluded that the intrinsic WUE of trees can be also associated with anthropogenic effects, such as, industrial factories, vehicles, and low stack emission of $\mathrm{CO}_{2}$ (Waterhouse et al., 2004; Saurer et al., 2014). An elevated $\mathrm{CO}_{2}$ level significantly decreases the $\delta^{13} \mathrm{C}$ in the air (Keeling et al., 1996). Across all the sites, elevated $\mathrm{CO}_{2}$ levels increased the ${ }^{13} \mathrm{C}$-derived $i W U E$, and a positive land-surface temperature anomaly- $i W U E$ relationship was observed. According to NASA, land surface temperature differs from air temperature because land heats and cools more quickly than air. The most recent literature on this topic (for example, Stips et al., 2016) confirms that the greenhouse gases are the main drivers of the changing global surface-air temperature (NASA). In our study, it has been observed that elevated $\mathrm{CO}_{2}$ levels increase the intrinsic WUE of forests, but the magnitude of this effect and its interaction with climate are still poorly understood. In the investigated forests, the pine trees in each population show different sensitivities to weather conditions. The detailed relationship between the isotope time series and the biosphere-contamination records will be the subject of a further publication.

\section{CONCLUSIONS}

This study revealed that the Scots-pine populations did not show radial-growth differences within the same climatic microregion, and could be considered dendrochronologically homogeneous. The delineation of three dendrochronologically homogeneous regions was important for the dendroclimatological work. The similarity of the short-term signal in the tree-ring width decreased with the distance between regions, but was often high between sites from various regions. Therefore, the geographical criterion did not sufficiently explain the grouping of the pine populations.

The long and frosty winters had a negative impact on the radial growth of the pines in all the regions. Pine trees were also sensitive to a shortage of rainfall during July, the period of intense vascular-cambium division. However, Scots pine also demonstrated characteristic sensitivity to the climatic conditions of the region in which it grew. The specific impact on the radial growth of the pines depended on the pluvial condition in June, and the thermal condition in July, in each of the three regions.

The present investigation also showed differences in the relationship between climate and the stable isotopic composition of pine populations growing in the same climatic microregion. The importance of the current growing-season climate was revealed, and the impact of the other months was detected. The signals of climate changes recorded in the stable isotope composition of tree-ring cellulose was not stable over time. Relationships between $\delta^{13} \mathrm{C}$ and temperature were positive and between $\delta^{13} \mathrm{C}$ and sunshine positive, whereas relationships between $\delta^{13} \mathrm{C}$ and precipitation were negative and between $\delta^{13} \mathrm{C}$ and humidity negative. The relationship between $\delta^{18} \mathrm{O}$ and temperature was positive, and between $\delta^{18} \mathrm{O}$ and humidity negative. These relationships were expected in the light of the theoretical backgrounds. However, the correlations showed some variations between the investigated sites. The effect of the climatic isotope signals in the tree rings can be masked by the biosphere contamination.

\section{ACKNOWLEDGMENTS}

The authors wish to express their sincere gratitude to everyone who contributed to making these investigations possible, particularly Magdalena Opała and the technical staff of Silesian University of Technology, who helped in the sample collection and technical work. This project was a part of "Trees as bioindicators of industrial air pollution during the implementation of the proenvironmental policy in the Silesia region (BIOPOL)" funded by the National Science Centre allocated from decision number DEC-2011/03/D/ST10/05251. This publication was supported by a grant (grant number 14/990/RGJ17/0077) for research and development, the Silesian University of Technology and the Silesian Uni- 
versity of Technology Rector's habilitation grant (14/990/RGH17/096).

\section{REFERENCES}

Anderson WT, Bernasconi SM, McKenzie JA and Saurer M, 1998. Oxygen and carbon isotopic record of climatic variability in tree ring cellulose, Picea abies.: An example from central Switzerland, 1913 -1995. Journal of Geophysical Research 103: 31625-31636, DOI 10.1029/1998JD200040.

Barbour MM, Roden JS, Farquhar GD and Ehleringer JR, 2004. Expressing leaf water and cellulose oxygen isotope ratios as enrichment above source water reveals evidence of a Peclet effect. Oecologia 138: 426-435, DOI 10.1007/s00442-003-1449-3.

Barbour MM, Walcroft AS and Farquhar GD, 2002. Seasonal variation in $\delta^{13} \mathrm{C}$ and $\delta^{18} \mathrm{O}$ of cellulose from growth rings of Pinus radiata. Plant, Cell and Environment 25: 1483-1499, DOI 10.1046/j.00168025.2002.00931.x.

Battipaglia G, Saurer M, Cherubini P, Calfapietra C, McCarthy HR, Norby RJ and Cotrufo MF, 2013. Elevated $\mathrm{CO}_{2}$ increases treelevel intrinsic water use efficiency: insights from carbon and oxygen isotope analyses in tree rings across three forest FACE sites. New Phytologist 197: 544-554, DOI 10.1111/nph.12044.

Balanzategui D, Knorr A, Heussner KU, Wazny T, Beck W, Słowiński M, Helle G, Buras A, Wilmking M, Van Der Maaten E, Scharnweber T, Dorado-Liñán I and Heinrich I, 2017. An 810-year history of cold season temperature variability for northern Poland. Boreas 47: 443-453, DOI 10.1111/bor.12274.

Boettger T, Haupt M, Friedrich M and Waterhouse JS, 2014. Reduced climate sensitivity of carbon, oxygen and hydrogen stable isotope ratios in tree-ring cellulose of silver fir, Abies alba Mill. influenced by background $\mathrm{SO}_{2}$ in Franconia, Germany, central Europe. Environmental Pollution 185: 281-294, DOI 10.1016/j.envpol.2013.10.030.

Biondi F, 1997. Evolutionary and moving response functions in dendroclimatology. Dendrochronologia 15: 139-150.

Boden TA, Marland G and Andres RJ, 2016. Global, Regional and National Fossil-Fuel $\mathrm{CO}_{2}$ Emissions. Carbon Dioxide Information Analysis Center, Oak Ridge National Laboratory, U.S. Department of Energy, Oak Ridge, Tenn., U.S.A., DOI 10.3334/CDIAC/00001 V2016.

Briffa KR and Jones PD, 1990. Basic chronology statistics and assessment. In: Cook ER and Kairiukstis LA, eds., Methods of dendrochronology. Applications in the environmental sciences. Kluwer Academic, Dordrecht: 137-152.

Burk RL and Stuiver M, 1981. Oxygen isotope ratios in trees reflect mean annual temperature and humidity. Science 211: 1417-1419, DOI 10.1126/science.211.4489.1417.

Cinnirella S, Magnani F, Saracino A and Borghetti M, 2002. Response of a mature Pinus laricio plantation to a three-year restriction of water supply: structural and functional acclimation to drought. Tree Physiology 22: 21-30, DOI 10.1093/treephys/22.1.21.

Craig H, 1954. Carbon-13 in plants and the relationship between carbon-13 and carbon-14 variations in nature. Journal of Geology 62: 115-149, DOI 10.1086/626141.

Cropper JP and Fritts HC, 1982. Density of tree-ring grids in western North America. Tree-Ring Bulletin 42: 3-10.

Edwards TWD and Fritz P, 1986. Assessing meteoric water composition and relative humidity from ${ }^{18} \mathrm{O}$ and ${ }^{2} \mathrm{H}$ in wood cellulose: paleoclimatic implications for southern Ontario, Canada. Applied Geochemistry 1(6): 715-723.

Edwards TWD, Graf W, Trimborn P, Stichler W, Lipp J and Payer HD, 2000. $\delta^{13} \mathrm{C}$ response surface resolves humidity and temperature signals in trees. Geochimica et Cosmochimica Acta 64: 161-167, DOI 10.1016/S0016-7037(99)00289-6.

Ehrelinger J and Vogel J, 1993. Historical Aspects of Stable Isotopes in Plant Carbon and Water Relations. In: Ehrelinger JR, Hall AE and Farquhar GD, eds., Stable isotopes and plant Carbon-Water Relation. Academic Press, New York, 9-19
Farquhar GD and Lloyd L, 1993. Carbon and oxygen isotope effects in the exchange of carbon dioxide between plants and the atmosphere. In: Ehrelinger JR, Hall AE and Farquhar GD, eds., Stable isotopes and plant Carbon-Water Relation. Academic Press, New York: $47-70$

Feliksik E and Wilczyński S, 2004. Teleconnection of tree-ring increment chronologies of Douglas fir, Pseudotsuga menziesii, Mirb.Franco: nationwide and regional increment patterns. Sylwan 148(12): 14-22.

Ferrio J, Voltas J and Araus J, 2003. Use of carbon isotope composition in monitoring environmental changes. Management of Environmental Quality 14: 82-98.

Fritts HC, 1976. Tree Rings and Climate. Academic Press, London: $567 \mathrm{pp}$.

Gagen M, Finsinger W, Wagner-Cremer F, McCarroll D, Loader N, Robertson I, Jalkanen R, Young G and Kirchhefer A, 2011. Evidence of changing intrinsic water-use efficiency under rising atmospheric $\mathrm{CO}_{2}$ concentrations in Boreal Fennoscandia from subfossil leaves and tree ring $\delta^{13} \mathrm{C}$ ratios. Global Change Biology 17: 1064-1072, DOI 10.1111/j.1365-2486.2010.02273.x.

Gagen M, McCarroll D and Edouard JL, 2004. The effect of site conditions on pine tree-ring width, density and $\delta^{13} \mathrm{C}$ series. Arctic, Antarctic, and Alpine Research, 36(2): 166-171.

Green J, 1963. Wood cellulose. In: Whistler RL ed., Methods in Carbohydrate Chemistry 3. Academic Press, New York: 9-21.

Gričar J, Zupancic M, Cufar K, Koch G, Schmitt UWE and Oven P, 2006. Effect of local heating and cooling on cambial activity and cell differentiation in the stem of Norway spruce, Picea abies. Annals of Botany 97(6): 943-951, DOI 10.1093/aob/mc1050.

Helama S, Lindholm M, Meriläinen J, Timonen M and Eronen M, 2005. Multicentennial ring-width chronologies of Scots pine along northsouth gradient across Finland. Tree-Ring Research 61: 21-32, DOI 10.3959/1536-1098-61.1.21.

Helama S, Lindholm M, Timonen M, Meriläinen J and Eronen M, 2002. The supra-long Scots pine tree-ring record for Finnish lapland: part 2 , interannual to centennial variability in summer temperatures for 7500 years. Holocene 12: 681-687, DOI 10.1191/0959683602hl581rp.

Hoch G, Richter A and Körner C, 2003. Non-structural carbon compounds in temperate forest trees. Plant, Cell and Environment 26(7): 1067-1081, DOI 10.1046/j.0016-8025.2003.01032.x.

Holmes RL, 1983. Computer-assisted quality control in tree-ring dating and measurement. Tree-Ring Bulletin 43: 69-78.

Irvine J, Perks MP, Magnani F and Grace J, 1998. The response of Pinus sylvestris to drought: stomatal control of transpiration and hydraulic conductance. Tree Physiology 18: 393-398.

Keeling CD, Chin JFS and Whorf TP, 1996. Increased activity of northern vegetation inferred from atmospheric $\mathrm{CO}_{2}$ measurements. $\mathrm{Na}$ ture 382: $146-149$, DOI 10.1038/382146a0.

Leavitt S and Long A, 1982. Stable carbon isotopes as a potential supplemental tool in dendrochronology. Tree Ring Bulletin 42: 4956.

Leegood RC and Edwards GE, 1996. Carbon metabolism and photorespiration: temperature dependence in relation to other environmental factors. In: Baker NR, ed., Photosynthesis and the Environment. Kluwer Academic, Dordrecht: 191-221.

Leonelli G, Battipaglia G, Siegwolf RTW, Saurer M, di Cella UM, Cherubini $\mathrm{P}$ and Pelfini M, 2012. Climatic isotope signals in tree rings masked by air pollution: A case study conducted along the Mont Blanc Tunnel access road, Western Alps, Italy. Atmospheric Environment 61: 169-179, DOI 10.1016/j.atmosenv.2012.07.023.

Lindholm M, Lehtonen H, Kolström T, Meriläinen J, Eronen M and Timonen M, 2000. Climatic signals extracted from ring-width chronologies of Scots pine from the northern, middle and southern parts of the boreal forest belt in Finlands. Silva Fennica 34: 317329.

Lindholm M, Meriläinen J, Timonen M, Vanninen P and Eronen M, 1997. Effects of climate on the growth of Scots pine in the Saimaa Lake District, south-eastern Filand, in the southern part of the boreal forest belt. Dendrochronologia 15: 151-168. 
Macias M, Timonen Kirchhefer A, Lindholm M, Eronen M and Gutierrez E, 2004. Growth variability of Scots pine along a westeast gradient across northern Fennoscandia: a dendroclimatic approach. Arctic, Antractic, and Alpine Research 36: 565-574, DOI 10.1657/1523-0430(2004)036[0565:GVOSPP]2.0.CO;2.

Mäkinen H, Nöjd P and Mielikäinen K, 2000. Climatic signal in annual growth variation of Norway spruce, Picea abies. along a transect from central Finland to the Arctic timberline. Canadian Journal of Forest Research 30: 769-777, DOI 10.1139/cjfr-30-5-769.

Malik I, Danek M, Marchwinska-Wyrwal E, Danek T, Wistuba M and Krąpiec M, 2012. Scots Pine (Pinus sylvestris L.) Growth Suppression and Adverse Effects on Human Health Due to Air Pollution in the Upper Silesian Industrial District (USID) Southern Poland. Water, Air, and Soil Pollution 223: 3345-3364, DOI 10.1007/s11270-012-1114-8.

Martin B, Bytnerowicz A and Thorstenson YR, 1988. Effects of air pollutants on the composition of stable carbon isotopes, $\delta^{13} \mathrm{C}$. of leaves and wood and on leaf injury. Plant Physiology 88: 218-223, DOI 10.1104/pp.88.1.218.

McCarroll D and Loader NJ, 2004. Stable isotopes in tree rings. Quaternary Science Reviews 23: 771-801, DOI 10.1016/j.quascirev.2003.06.017.

McCarroll D, Gagen MH, Loader NJ, Robertson I, Anchukaitis KJ, Los S, Young GHF, Jalkanen R, Kirchhefer A and Waterhouse JS, 2009. Correction of tree ring stable carbon isotope chronologies for changes in the carbon dioxide content of the atmosphere. Geochimica et Cosmochimica Acta 73(6): 1539-1547, DOI 10.1016/j.gca.2008.11.041.

NASA, http://climate.nasa.gov/vital-signs/carbon-dioxide. Accessed 2018 May./

NOAA, https://www.esrl.noaa.gov/. Accessed 2018 May.

Pazdur A, Kuc T, Pawełczyk S, Piotrowska N, Sensuła BM and Różański K, 2013. Carbon Isotope Composition of Atmospheric Carbon Dioxide in Southern Poland: Imprint of Anthropogenic $\mathrm{CO}_{2}$ Emissions in Regional Biosphere. Radiocarbon 55(2-3): 848-864, DOI 10.1017/S003382220005801X.

Pazdur A, Nakamura T, Pawełczyk S, Pawlyta J, Piotrowska N, Rakowski A, Sensuła B and Szczepanek M, 2007. Carbon isotopes in tree rings: climate and human activities in the last 400 years. Radiocarbon 49(2): 1133-1143.

Piovesan G, Biondi F, Di Filippo A, Alessandrini A and Maugeri M, 2008. Drought-driven growth reduction in old beech, Fagus sylvatica. forests of the central Apennines, Italy. Global Change Biology 14: 1265-1281, DOI 10.1111/j.1365-2486.2008.01570.x.

Richter K, Eckstein D and Holmes RL, 1991. The dendrochronological signal of the pine trees, Pinus sp. in Spain. Tree-Ring Bulletin 51: $1-13$.

Rinne KT, Loader NJ, Switsur VR, Treydte KS and Waterhouse JS, 2010. Investigating the influence of sulphur dioxide, $\mathrm{SO}_{2}$ on the stable isotope ratios, $\delta^{13} \mathrm{C}$ and $\delta^{18} \mathrm{O}$ of tree rings. Geochimica et Cosmochimica Acta 74: 2327-2339, DOI 10.1016/j.gca.2010.01.021.

Roden J, 2008. Cross-dating of tree-ring $\delta^{18} \mathrm{O}$ and $\delta^{13} \mathrm{C}$ time series. Chemical Geology 252: 72-79, DOI 10.1016/j.chemgeo.2008.01.007.

Roden J, Lin G and Ehleringer J, 2000. A mechanistic model for the interpretation of hydrogen and oxygen isotope ratios in tree-ring cellulose. Geochimica et Cosmochimica Acta 64: 21-35, DOI 10.1016/S0016-7037(99)00195-7.

Rossi S, Deslauries A, Gričar J, Seo JW, Rathegeber C.B, Anfodillo T, Morin H, Levanic T, Oven P and Jalkanen R, 2008. Critical temperatures for xylogenesis in conifers of cold climates. Global Ecology and Biogeography 17(6): 696-707, DOI 10.1111/j.14668238.2008.00417.x.

Rozanski K, Arguas-Arguas L and Gonfiantini R, 1993. Isotopic patterns in modern global precipitation. In: Swart PK, Lohmann KC, MacKenzie J and Savin S, eds., Climate Change in Continental Isotopic Records, AGU, Washington D.C.: 1-3.

Saurer M and Siegwolf RTW, 2007. Human impacts on tree-ring growth reconstructed from stable isotopes. In Dawson TE and
Siegwolf RTW eds., Stable isotopes as indicators of ecological change terrestrial ecology series. Elsevier, Amsterdam: 49-62.

Saurer M, Borella S, Schweingruber FH and Siegwolf RTW, 1997b. Stable carbon isotopes in tree rings of beech: Climatic versus siterelated influences. Trees - Structure and Function 11: 291-297, DOI $10.1007 / \mathrm{s} 004680050087$.

Saurer M, Schweingruber F, Vaganov EA, Shiyatov SG and Siegwolf $\mathrm{R}, 2002$. Spatial and temporal oxygen isotope trends at the northern tree-line in Eurasia. Geophysical Research Letters 29(9): 1296, DOI 10.1029/2001GL013739.

Saurer M, Siegwolf R and Schweingruber F, 2004. Carbon isotope discrimination indicates improving water-use efficiency of trees in northern Eurasia over the last 100 years. Global Change Biology 10: 2109-2120, DOI 10.1111/j.1365-2486.2004.00869.x.

Saurer M, Spahni R, Frank DC, Joos F, Leuenberger M, Loader NJ, McCarroll D, Gagen M, Poulter B, Siegwolf RTW, Andreu-Hayles L, Boettger T, Dorado Liñán I, Fairchild IJ, Friedrich M, Gutierrez E, Haupt M, Hilasvuori E, Heinrich I, Helle G, Grudd H, Jalkanen R, Levanič T, Linderholm HW, Robertson I, Sonninen E, Treydte K, Waterhouse JS, Woodley EJ, Wynn PM and Young GHF, 2014. Spatial variability and temporal trends in water-use efficiency of European forests. Global Change Biology 20: 3700-3712, DOI $10.1111 / \mathrm{gcb} .12717$.

Saurer M, Aellen K and Siegwolf R, 1997a. Correlating $\delta^{18} \mathrm{C}$ and $\delta^{18} \mathrm{O}$ in cellulose of trees. Plant, Cell and Environment 20: 1543-1550, DOI 10.1046/j.1365-3040.1997.d01-53.x.

Scheidegger Y, Saurer M, Bahn M and Siegwolf R, 2000. Linking stable oxygen and carbon isotopes with stomatal conductance and photosynthetic capacity: a conceptual model. Oecologia 125: 350357, DOI 10.1007/s004420000466.

Schleser GH, Helle G, Lucke A and Vos H, 1999. Isotope signals as climate proxies: The role of transfer functions in the study of terrestrial archives. Quaternary Science Reviews 18: 927-943, DOI 10.1016/S0277-3791(99)00006-2.

Schweingruber FH, 1985. Dendroecological zones in the coniferous forest of Europe. Dendrochronologia 3: 67-75.

Sensuła B and Pazdur A, 2013a. Influence of climate change on carbon and oxygen isotope fractionation factors between glucose and $\alpha$ cellulose of pine wood. Geochronometria 40(2): 145-152, DOI 10.2478/s13386-013-0104-y.

Sensuła B and Pazdur A, 2013b. Stable carbon isotopes of glucose received from pine tree-rings as bioindicators of local industrial emission of $\mathrm{CO}_{2}$ in Niepołomice Forest, 1950-2000. Isotopes in Environmental and Health Studies 49(4): 532-541, DOI 10.1080/10256016.2013.865026.

Sensuła B, 2016a. $\delta^{13} \mathrm{C}$ and water use efficiency in the glucose of annual pine tree-rings as ecological indicators of the forests in the most industrialized part of Poland. Water, Air, and Soil Pollution 227: 68, DOI 10.1007/s11270-016-2750-1.

Sensuła B, 2016b. The Impact of Climate, Sulfur Dioxide, and Industrial Dust on $\delta^{18} \mathrm{O}$ and $\delta^{13} \mathrm{C}$ in Glucose from Pine Tree Rings Growing in an Industrialized Area in the Southern Part of Poland. $\mathrm{Wa}$ ter, Air, and Soil Pollution 227: 106, DOI 10.1007/s11270-016$2808-0$.

Sensuła B, Opała M, Wilczyński S and Pawełczyk S, 2015a. Long-and short-term incremental response of Pinus sylvestris $L$. from industrial area nearby steelworks in Silesian Upland, Poland. Dendrochronologia 36: 1-12, DOI 10.1016/j.dendro.2015.08.001.

Sensuła B and Wilczyński S, 2017. Climatic signals in tree-ring width and stable isotopes composition of Pinus sylvestris L. growing in the industrialized area nearby Kędzierzyn-Koźle. Geochronometria 44: 240-255, DOI 10.1515/geochr-2015-0070.

Sensuła B, Wilczyński S, Monin L, Allan M, Pazdur A and Fagel N, 2017. Variations of tree ring width and chemical composition of wood of pine growing in the area nearby chemical factories. Geochronometria 44: 226-239, DOI 10.1515/geochr-2015-0064.

Sensuła B, Wilczyński S and Opała M, 2015b. Tree growth and climate relationship: Dynamics of Scots pine, Pinus sylvestris L. growing in the near-source region of the combined heat and power plant during the development of the pro-ecological strategy in Poland. 
Water, Air, and Soil Pollution 226: 220, DOI 10.1007/s11270-0152477-4.

Sensuła BM, Pazdur A and Marais MF, 2011. First application of mass spectrometry and gas chromatography in investigation of $\alpha$ cellulose hydrolysates: the influence of climate changes on glucose molecules in pine tree-rings. Rapid Communications in Mass Spectrometry 25(4): 489-494, DOI 10.1002/rcm.4882.

Siegenthaler U and Oeschger H, 1980. Correlation of ${ }^{18} \mathrm{O}$ in precipitation with temperature and altitude. Nature 285: 314-317, DOI $10.1038 / 285314 \mathrm{a} 0$.

Silva LCR and Horwath WR, 2013. Explaining Global Increases in Water Use Efficiency: Why Have We Overestimated Responses to Rising Atmospheric $\mathrm{CO}_{2}$ in Natural Forest Ecosystems? PLoS ONE 8(1): e53089, DOI 10.1371/journal.pone.0053089.

StatSoft Inc, 2014. STATISTICA, data analysis software system. version 12. http://www.statsoft.com/.

Stips A, Macias D, Coughlan C, Garcia-Gorriz E and Liang XS, 2016. On the causal structure between $\mathrm{CO}_{2}$ and global temperature. Scientific Reports 6: 21691, DOI 10.1038/srep21691.

Switsur R and Waterhouse J, 1998. Stable isotopes in tree ring cellulose. In Griffiths $\mathrm{H}$ ed.,Stable Isotopes. Bios Scientific, Oxford: 303321.

Szczepanek M, Pazdur A, Pawełczyk S, Boettger T and SzychowskaKrapiec E, 2006. Hydrogen, carbon and oxygen isotopes in pine and oak tree rings from Southern Poland as climatic indicators in years 1900-2003. Geochronometria 25: 67-76.

Treydte K, Frank D, Esper J, Andreu L, Bednarz, Z, Berninger, F, Boettger T, D'Alessandro C, M, Etien N, Filot M, Grabner M, Guillemin M, T, Gutierrez E, Haupt M, Helle G, Hilasvuori E, Jungner H, Kalela-Brundin M, Krapiec M, Leuenberger M, Loader NJ, Masson-Delmotte V, Pazdur A, Pawelczyk S, Pierre M, Planells O, Pukiene R, Reynolds-Henne CE, Rinne KT, Saracino A, Saurer M, Sonninen E, Stievenard M, Switsur VR, Szczepanek
M, Szychowska-Krapiec E, Todaro L, Waterhouse J S, Weigl M and Schleser GH, 2007. Signal strength and climate calibration of a European tree-ring isotope network. Geophysical Research Letters 34: L24302, DOI 10.1029/2007GL031106.

Vaganov EA, Hughes MK and Shaskin AV, 2006. Growth dynamics of conifer tree rings-images of past and futures environments. Springer, Heidelberg: $354 \mathrm{pp}$.

Waterhouse JS, Switsur VR, Barker AC, Carter AHC, Hemming DL, Loader NJ and Robertson I, 2004. Northern European trees show a progressively diminishing response to increasing atmospheric carbon dioxide concentrations. Quaternary Science Reviews 23: 803810, DOI 10.1016/j.quascirev.2003.06.011.

Wigley TM, Briffa KR and Jones PD, 1984. On the average value of correlated time series, with applications in dendroclimatology and hydrometeorology. Journal of Applied Meteorology and Climatology 23: 201-213, DOI 10.1175/15200450(1984)023<0201:OTAVOC>2.0.CO;2.

Wilczyński S and Skrzyszewski J, 2002. The climatic signal in treerings of Scots pine, Pinus sylvestris L. from foot-hills of the Sudetic Mountains, southern Poland. Forestwisenschaftliches Centralblatt 121: 15-24, DOI 10.1046/j.1439-0337.2002.01042.x.

Wilczyński S and Szymański N, 2015. Climatic signal in the tree-ring series of Norway spruces from the lower and upper montane forest belt in the Tatra Mountains. Sylwan 159(12): 1008-1017.

Wilczyński S, Krąpiec M, Szychowska-Krąpiec E and Zielski A, 2001. Dendroclimatic regions of Scots pine, Pinus sylvestris L. in Poland. Sylwan 8: 53-61.

Yakir D, DeNiro MJ and Gat J, 1990. Natural Deuterium and oxygen-18 enrichment in leaf water of cotton plants grown under wet and dry conditions: Evidence for water compartmentalization and its dynamics. Plant Cell and Environment 13: 49-56.

Yoder BJ, Ryan MG, Waring RH, Schoettle AW and Kaufmann MR, 1994. Evidence of reduced photosynthetic rates in old trees. Forest Science 40: 513-527. 